\title{
Vormen van politiek. Veranderingen van de openbaarheid in Nederland 1848-1900
}

\author{
IDO DE HAAN en HENK TE VELDE
}

Sinds jaar en dag trekken vooral twee aspecten van de Nederlandse politiek na 1848 de aandacht van onderzoekers 1 . Ten eerste is er belangstelling voor wat formeel als politiek geldt, vooral het parlementaire werk en de daaraan verbonden wetgeving, discussie en groepsvorming. Aanvankelijk hielden vooral liberale juristen (zoals Van Weideren Rengers en later Oud) zich bezig met deze zijde van de politieke geschiedenis; in de laatste decennia ontstonden op dit terrein verscheidene onderzoeks- en documentatiecentra. Ten tweede bestudeerden confessionelen en socialisten de politiek als instrument van emancipatie. Met een ander perspectief en andere accenten zet het verzuilingsonderzoek deze onderzoekstraditie voort. Daarin gaat het meestal om de wijze waarop de verzuiling een antwoord op maatschappelijke modernisering of een bedding daarvoor bood. Politiek is dan afspiegeling van verzuiling of emancipa$\mathrm{tie}^{2}$.

Beide vormen van onderzoek hebben hun grote verdiensten en vormen een onmisbaar uitgangspunt voor alle verdere studie. Toch bestaat al meer dan tien jaar behoefte aan vernieuwing en is de aandrang daartoe de laatste jaren sterker geworden ${ }^{3}$. In dit verband valt vaak de term 'politieke cultuur'. De omschrijving van het object van de studie van politieke cultuur munt tot dusver niet uit door helderheid en het is waarschijnlijk beter voorlopig de belangstelling ervoor te nemen voor wat ze is: een poging politieke geschiedenis uit te breiden door naast parlement, partij, pers en idee ook stijl en mentaliteit in de beschouwing te betrekken. Als zodanig duidt ze op een verschuiving in de benadering van de politieke geschiedenis. Als we politiek noch beschouwen als een vanzelfsprekende overlegpraktijk in formele organen, noch als een automatische afspiegeling van maatschappelijke ontwikkelingen, dan moeten we ons weer gaan bezinnen op de vraag wat 'politiek' inhield in de negentiende eeuw.

Het al weer enkele decennia oude werk van John Vincent, The formation of the British Liberal Party 1857-1868 is een goed antwoord op deze vraag. Vincent beschrijft niet alleen de parlementaire situatie, maar ook de buitenparlementaire politiek, de groei van een nieuwe pers, de typen van politiek leiderschap, de verhouding tussen leider en achterban en de verhouding tussen lokale en nationale politiek ${ }^{4}$. Hij beschrijft de

1 Voor hun uitgebreide commentaar op een eerdere versie willen we vooral prof. dr. Coen Tamse, drs. Stefan Dudink, prof. dr. Piet de Rooy en prof. dr. Siep Stuurman danken.

2 Men zie voor het eerste onder meer het opstel van Bosnians in P. Luykx en N. Bootsma, ed., De laatste tijd. Geschiedschrijving over Nederland in de 20e eeuw (Utrecht, 1987) en voor het tweede de betreffende opstellen aldaar (als ook de inleiding van Luykx) en die van Ten Have en Blaas in: W. W. Mijnhardt, ed., Kantelend geschiedbeeld. Nederlandse historiografie sinds 1945 (Utrecht, 1983).

3 Vergelijk de rede van P.. de Rooy, Geen ideaal dat ons toelacht? (Amsterdam, 1994).

4 Oorspronkelijk 1966; hier gebruikte tweede editie (Hassocks-Londen, 1976). De problematiek van Vincent werd opnieuw besproken in E. F. Biagini, Liberty, retrenchment and reform. Popular liberalism in the age of Gladstone, 1860-1880 (Cambridge etc., 1992). 
verandering van wat men zou kunnen noemen de openbare sfeer of openbaarheid, van de plaats waar publiekelijk over politiek gesproken werd en van de manier waarop dat ging. Nederlandse historici hebben deze kwestie nu en dan ook wel aangesneden. Zo toonde Rüter al in de jaren dertig een fijn gevoel voor de stijl van vroeg-socialistische politiek en geeft het recente onderzoek naar lokale verzuiling veel voorbeelden van vormverandering in de politiek van de tweede helft van de negentiende eeuw ${ }^{5}$. De vormverandering als zodanig is echter nog geen zelfstandig onderwerp van studie geweest.

Ons voorstel om de veranderende vorm van de openbaarheid te bestuderen sluit aan bij de gedachte dat politiek niet vanzelfsprekend met de staat verbonden is. 'Politiek' is allereerst een strijd om de vraag wat politiek is en waarmee politiek zich mag en kan bezighouden ${ }^{6}$. Daarin is de staat weliswaar een belangrijke factor, maar omvang, taak en vermogen van de staat zijn nu juist ook het produkt van politieke strijd buiten de staat. Tegenwoordig gaat de aandacht van onderzoekers daarom ook uit naar de plek waar (democratische) politiek ontstaat en de wijze waarop dat gebeurt, kortom naar 'de openbaarheid ${ }^{7}$.

De geschiedschrijving van de openbaarheid is sterk beïnvloed door Jürgen Habermas' Strukturwandel der Öffentlichkeit 8. Habermas heeft daarin de ontwikkeling van de openbaarheid in twee fasen ingedeeld. De eerste fase zou in de achttiende eeuw zijn begonnen met de bloei van de openbaarheid in kranten en tijdschriften, genootschappen en clubs, waartoe in beginsel iedere burger toegang had. Beschaving was weliswaar een voorwaarde voor volwaardige deelname, maar deelname leidde op zichzelf ook tot beschaving. Het vrije en voor alle burgers toegankelijke debat legitimeerde de machtsuitoefening. De tweede fase zou in de tweede helft van de negentiende eeuw zijn aangevangen en het karakter dragen van een Verfallsgeschichte. De openbaarheid bleek in haar praktische vormgeving slechts toegankelijk voor huisvaders uit de bezittende klasse. Daardoor ontstonden maatschappelijke spanningen die opgevangen

5 A.J.C. Rüter, De spoorwegstakingen van 1903. Een spiegel der arbeidersbeweging in Nederland (Ie ed. 1935; Nijmegen, s. a.); vooral R. van der Laarse, Bevoogding en bevinding. Heren en kerkvolk in een Hollandse provinciestad, Woerden 1780-1930 (Den Haag, 1989); B. Altena, 'Een broeinest der anarchie'. Arbeiders, arbeidersbeweging en maatschappelijke ontwikkeling. Vlissingen 1875-1929 (1940) (Amsterdam, 1989); J. Leenders, Benauwde verdraagzaamheid, hachelijk fatsoen. Families, standen en kerken te Hoorn in het midden van de negentiende eeuw (Den Haag, 1992); J. van Miert, Wars van clubgeest en partijzucht. Liberalen, natie en verzuiling, Tiel en Winschoten 1850-1920 (Amsterdam, 1994).

6 I. de Haan, Zelfbestuur en staatsbeheer. Hel politieke debat over burgerschap en rechtsstaat in de twintigste eeuw (Amsterdam, 1993).

7 In dit verband wordt ook wel het begrip civil society gebruikt, maar daaronder wordt vaak niet alleen politiek verstaan maar ook cultuur en vooral economie ('markt'), kortom alles tussen individu en staat. Zie voor de recente populariteit van het begrip o. a. E. Gellner, Conditions of liberty. Civil society and its rivals (Londen, 1994)hfdst. 1 en passim;de dubbelzinnigheden ervan worden besproken inj. Keane,'Despotism and democracy. The origins and development of the distinction between civil society and the state 1750 1850', in: Idem, ed., Civil society and the state. New european perspectives (Londen-New York, 1988) 35 71 en K. Kumar, 'Civil society. An inquiry into the usefulness of an historical term', The British journal of sociology, XLIV (1993) 375-395.

8 J. Habermas, Strukturwandel der Öffentlichkeit. Untersuchungen zu einer Kategorie der bürgerlichen Gesellschaft (Neuwied-Berlijn, 1962). 
werden door de staat. $\mathrm{Nu}$ werd de staat niet langer gecontroleerd vanuit de openbaarheid, maar ging de eerste de laatste juist beheersen. De legitimatie van machtsuitoefening was nu volgens Habermas verworden tot manipulatie van de massa en het afkopen van maatschappelijke onvrede met sociale voorzieningen.

Wij laten ons inspireren door Habermas, maar ook door de kritiek die de beperkingen van zijn benadering heeft duidelijk gemaakt ${ }^{9}$. Voor ons doel zijn vooral drie kanttekeningen relevant. Ten eerste heeft Habermas niet duidelijk gemaakt hoe en wanneer de burgerlijke openbaarheid van verenigingen tot een (liberale) politieke openbaarheid werd; ten tweede heeft hij het ideaal van vrije toegang gescheiden van de praktische uitsluiting van vrouwen en ook volksklassen op basis van verondersteld vrouwelijke kenmerken als wispelturigheid, sentimentaliteit en vatbaarheid voor fantasie; ten derde was de staat niet eerst de afspiegeling en later de manipulator van de burgerlijke openbaarheid maar was de verhouding tussen beide veel ingewikkelder.

Tegen deze achtergrond zullen wij ten eerste laten zien hoe de burgerlijke openbaarheid in Nederland onder liberale invloed eigenlijk pas na 1848 de grondslag werd voor de legitimatie van politieke macht. Tegenover het belang dat conservatieven als vanzelfsprekend hechtten aan particuliere, vaak zelfs familiale banden in de politiek, stelden liberalen dat machtsuitoefening slechts legitiem was als zij publiekelijk controleerbaar was en gerechtvaardigd werd in een debat dat abstraheerde van particuliere belangen, behoeften en voorkeuren. Deze hooggestemde idealen betekenden de uitsluiting van hen die een tekort aan zelfbeheersing en ontwikkeling toonden. De bloei van de liberale openbaarheid betekende daarom geen radicale wijziging van de sociale samenstelling van de groep van politiek actieve burgers.

Vervolgens betogen wij dat zich in de jaren 1880 een nieuwe vorm van openbaarheid ontwikkelde die onder meer in socialistische en antirevolutionaire partijvorming tot uiting kwam. $\mathrm{Nu}$ werden sentiment en groepsbelang juist expliciet aangesproken, maakte meningsvorming via het openbare debat plaats voor mobiliserende retoriek onder politiek gelijkgestemden en werd zo op een nieuwe manier de politieke deelname van de bevolking gestimuleerd.

Ten derde zullen wij laten zien dat de verandering van de openbaarheid mede tot stand kwam door een verandering in het optreden van de staat. Dit blijkt uit het voorbeeld van de overheidsstatistiek. Terwijl de statistiek binnen het liberale model van de openbaarheid gold als bijdrage aan de voorlichting van de publieke opinie, ontwikkelde zij zich tot instrument dat de behoeften van de bevolking tot grondslag van politieke macht maakte in plaats van de gefundeerde meningen van de burgerij.

Ook de tijdgenoten merkten deze veranderingen op, vooral doordat politici zich anders gingen gedragen en anders gingen spreken. Wij belichten daarom de stijlveran-

9 Kritisch gebruik van Habermas bijvoorbeeld in J. B. Landes, Women and the public sphere in the age of the French Revolution (Ithaca, 1988); L. Hunt, Politics, culture, and class in the French Revolution (Berkeley, 1984); G. Lottes, Politische Aufklärung und plebejiisches Publikum. Zur Theorie und Praxis des englischen Radikalismus im späten 18. Jahrhundert (München, 1979); G. Eley, 'Nations, publics, and political cultures: placing Habermas in the nineteenth century', in: C. Calhoun, ed., Habermas and the public sphere (Cambridge-Londen, 1992) 289-339. 
dering in de politiek, die behalve een essentieel onderdeel, ook een goede graadmeter is voor de veranderingen in de openbaarheid in de periode die wij beschrijven.

\section{Liberale openbaarheid, 1848-1870}

Het onderzoek naar lokale varianten van verzuiling heeft duidelijk gemaakt dat de politiek van de negentiende eeuw tekort wordt gedaan als ze slechts wordt beschreven als de groei van landelijke, levensbeschouwelijk georiënteerde organisaties. We zien dan namelijk twee zaken over het hoofd die in de negentiende eeuw nog van eminent belang waren ${ }^{10}$. Ten eerste de factor van stand: het sociale leven verliep langs sociale scheidslijnen en politiek was aanvankelijk exclusief een kwestie van een bepaalde sociale laag. Niet verwonderlijk blijkt het belang van dit aspect vooral in onderzoek waarin niet de teleologie van de twintigste-eeuwse sociaal-democratische of confessionele groepen centraal staat ${ }^{11}$. Ten tweede is duidelijk geworden dat de negentiendeeeuwse maatschappij lokaler georiënteerd was dan een twintigste-eeuws perspectief zou doen vermoeden. In politiek opzicht was er een groot verschil tussen nationaal en lokaal en was het nationale niveau niet zonder meer de som van al het lokale ${ }^{12}$.

Beide factoren hebben grote invloed gehad op de vorm die de doctrinair-liberale politiek na 1848 aannam. Liberalen streden voor het 'algemeen belang' en dit betekende allereerst dat zij nationale boven lokale verlangens stelden. De liberale politiek diende zich aan als nationale politiek, in de zin van politiek die zich had losgemaakt uit particularisme en lokale context. Het doctrinaire liberalisme wilde abstraheren van provincialisme, clientélisme, familiebanden. Alles wat deze 'abstracte' vorm van politiek in de weg stond, vervulde liberalen met afschuw. 'Een parlement dient om het algemeen belang voor te staan' heette het in 'Parasitische politiek', een Gids-artikel uit 1861 dat Thorbeckes aanval op Van Hall ondersteunde. De handige manoeuvres waarmee Van Hall de spoorwegaanleg door het parlement loodste, waren niet anders dan 'de koncessie eener zwakke regering aan de eischen van het provincialisme ${ }^{13}$. Zoals bekend was Van Hall Thorbeckes bête noire en, ook al was er persoonlijke animositeit in het spel, hij vertegenwoordigde inderdaad veel van wat de doctrinaire liberalen niet bezaten en ook niet wilden bezitten. Hij was een praktisch bestuurder in plaats van een principieel gemotiveerd politicus en trachtte pragmatisch 'een politiek van de middenweg te houden tusschen de beide uitersten, die er mogten blijken te bestaan' $^{14}$. Belangrijker nog was dat hij kwesties regelde via — zoals hij het zelf uitdrukte - 'den invloed mijner vrienden' ${ }^{15}$. De financiële hervorming van de jaren 1840 waarop hij hier doelde, deed Potgieter tegenover Bakhuizen van den Brink

10 Bij het volgende ook P. de Rooy, 'Zes studies over verzuiling', Bijdragen en mededelingen betreffende de geschiedenis der Nederlanden, CX (1995) 380-392.

11 Zie Van Miert, Tiel en Winschoten, over de verknoping van liberalisme en standsbesef en het synchroon georganiseerde boek van Leenders, Hoorn. Enkele jaren eerder vroeg Altena, Vlissingen, al overtuigend aandacht voor het belang van stand in de ontwikkeling van politiek.

12 Zie bijvoorbeeld Van Miert, Tiel en Winschoten en Van der Laarse, Woerden.

13 'Parasitische politiek', De Gids (1861) i, 143 en 165.

14 Uitspraak uit 1855 geciteerd in: J. G. Gleichman, Mr. F. A. van Hall als minister. Mededeelingen en herinneringen (Amsterdam, 1904) 209.

15 Aantekeningen van Van Hall: Ibidem, 93. 
verzuchten: 'Gij weet niet, hoe vermogend de invloed van dat geslacht is geworden sedert de lening van Maart '44 er door is' ${ }^{16}$. Zijn politiek berustte dus op connecties en succes verhoogde het aanzien van zijn Amsterdamse familieclan. Een liberaal als Thorbecke kon niet op verwanten steunen, bezat slechts politieke en universitaire contacten en zijn successen gaven zijn familie geen 'invloed'.

De op het 'abstracte' algemeen belang gerichte liberale politiek vroeg om eigen vormen. Liberalen verzetten zich tegen het paternalisme en harmonie-denken dat de regering van Willem I had gekenmerkt, maar zochten geen aansluiting bij de gebruiken van de woelige periode van de 'uitvinding' van de politiek, de patriottentijd ${ }^{17}$. Doctrinaire liberalen wensten ruimte voor meningsverschil in de politiek, maar dan wel in beschaafde trant. Zij stimuleerden dus het debat, maar letten daarbij op de juiste vormen. $\mathrm{Nu}$ was de liberale cultuur voor een belangrijk deel een schriftelijke cultuur van brochures, polemiek en Gi'cts-recensies ${ }^{18}$. Maar men kon zich ook in besloten kring oefenen 'in mondelingen redetwist, door het bespreken van vraagpunten van algemeen belang'. Op allerlei plaatsen in het land werden debating societies opgericht waar op het scherpst van de snede gedebatteerd werd. Het ging niet allereerst om de uitkomst van het debat maar om het genoegen van de redetwist zelf en om het treffen van de juiste 'parlementaire' toon. Het viel overigens niet mee de vormelijke parlementaire taal in de lokale gemeenschap te introduceren. In Haarlem bijvoorbeeld werd de 'meer gekuischten en deftigen parlementairen redeneertrant' niet consequent gehanteerd, omdat de sprekers elkaar uit de plaatselijke gemeenschap goed kenden. Met enige kunstgrepen werd daar de illusie van strijd in de parlementaire arena hersteld ${ }^{19}$.

Open debat binnen de grenzen van een spel, daar ging het om. De debating club bood een vorming maar veronderstelde zelf eigenlijk al een liberale Bildung, zodat weliswaar kleine burgers ${ }^{20}$ en een bloembollenhandelaar als F. W. van Eeden te Haarlem lid waren, maar plaatselijke juristen en notabelen in de dop toch de toon zetten. Later

16 Brief uit 1845, geciteerd in: L. C. Suttorp, F. A. van Hall en zijne conslilulioneele beginselen (Amsterdam, 1932) 20. Een opmerking over de familiesaamhorigheid in M. C. van Hall, Drie eeuwen. De kroniek van een Nederlandse familie (Amsterdam, 1961) 64.

17 N. C. F. van Sas, 'Tweedragt overal. Het patriottisme en de uitvinding van de moderne politiek', in: H. Bots, W. W. Mijnhardt, ed., De droom van de revolutie. Nieuwe benaderingen van hel patriottisme (Amsterdam, 1988) 18-31; een recent overzicht is S. R. E. Klein, Patriots republikanisme. Politieke cultuur in Nederland (1766-17S7) (Amsterdam, 1995).

18 De kwestie van de openbaarheid is natuurlijk ook nauw verbonden met de ontwikkeling van de pers; een volledig overzicht—dat hier niet wordt nagestreefd—zou hieraan zeker aandacht dienen te besteden. 19 Citaten en opmerkingen over Haarlem (met onder anderen Busken Huet en J. Th. Buys) en Amsterdam uit N. Maas, 'De Vereeniging. Debating Society', in: W. van den Berg, H. Eyssens, T. van Kalmthout, ed., Haarlemse kringen. Vijftien verkenningen naar het literair-culturele leven in een negentiende-eeuwse stad (Hilversum, 1993) 119-128. Zie ook E. H. Krelage, De Haarlemsche Debating Society (1853-1899) (Haarlem, 1935). Debating societies bestonden in ieder geval in Amsterdam, Rotterdam, Haarlem, Leiden, Den Haag, Goes, Middelburg, Zutphen, Leeuwarden; de meeste werden in de jaren vijftig opgericht. Vergelijk J. Helsloot, Vermaak tussen beschaving en kerstening. Goes 1867-1896 (Amsterdam, 1995) 409 met noten.

20 Vergelijk J. van der Kluit, 'Zoekend naar de waarheid - De 'Kring voor Wetenschappelijk Onderhoud' in de negentiende eeuw', in: B. Looper, J. C. Riemens, ed., Geschiedenis in Zutphen. Over geschiedschrijving, geschiedbeoefening en historisch besef(Zutphen, 1988) 113-121. 
bestonden er ook debating clubs van werklieden en drong de debating-rage zelfs tot de koninklijke familie door ${ }^{21}$, maar in aanleg was het een burgerlijke aangelegenheid. De liberaal-burgerlijke opvatting van politiek bepaalde er de ruimte en de grenzen van het spel, zoals de leidende rol van Alberdingk Thijm in de belangrijkste debating society, de al van 1846 daterende Vrijdagsche Vereeniging te Amsterdam, kan illustreren. De debating club was geen liberaal partij-orgaan en de overtuigde katholiek Alberdingk Thijm, die in een aantal opzichten bezwaren had tegen de liberale politiek, kon zich er dus thuis voelen. Anderzijds bleef de beschaafde burger Thijm binnen de grenzen van het liberaal-burgerlijke milieu: hij was geen confessioneel en stelde de liberale opvatting van cultuur en politiek niet ter discussie. In de Haagse Vereeniging tot oefening in het voeren van debatten traden, zo merkt een chroniqueur op, later 'Gunning en Domela Nieuwenhuis op, de toekomstige kerkelijke professor in de theologie en de toekomstige leider der socialisten, beiden dwepers, beiden ongeschikte debaters ook, omdat zij vooraf een grens stelden, die zij niet wilden overschrijden ${ }^{22}$. Om hun politieke doelen te bereiken moesten liberalen zich ook zelf bedienen van middelen die de politieke betrokkenheid van de kiesgerechtigden stimuleerden, maar een zekere beperking inhielden van het open debat. Zij richtten kiesverenigingen op, wat pas onder de grondwet van 1848 was toegestaan. Ook toen bestonden er geen partijen; het politieke standpunt van kandidaten was vaak slechts in algemene zin bekend $^{23}$ en notabelen konden per ongeluk worden benoemd tot bestuurslid van een kiesvereniging wier beginselen zij niet deelden ${ }^{24}$. Maar overal ontstonden openbare kiesverenigingen die in het begin soms fungeerden als open forum, als debating societies in het groot. Toen de overvalstechniek van een minderheid er hier en daar toe leidde dat ongewenste kandidaten werden gekozen, namen zij een meer besloten karakter aan. Van algemeen politiek forum werden ze pressiegroep voor een bepaalde politieke overtuiging ${ }^{25}$. Dat beviel niet iedereen en tot in de jaren 1870 verzette een enkele doctrinaire liberaal zich tegen het fenomeen van de kiesvereniging als een coterie die via haar 'voogdij ' over de kiezers een nieuwe vorm van getrapte verkiezin-

21 Bijvoorbeeld J. J. Giele, De Eerste Internationale in Nederland. Een onderzoek naar het ontstaan van de Nederlandse arbeidersbeweging van 1866 tot 1876 (Nijmegen, 1973) 139 en 167 (werklieden te Amsterdam 1871); J. J. Huizinga, J. Heemskerk Azn. (1818-1897). Conservatief zonder partij (Harlingen, 1973) 92 en F. Netscher, Theo (Amsterdam, 1911 ) 11 -15 (te Leiden 1868: onder anderen Th. Heemskerk, prins Alexander, W. van der Vlugt).

22 A. Ising, In de kamers der Staten-Generaal. Herinneringen en indrukken 1850-1886 ('s-Gravenhage, 1892) 107-109; hij plaatst de roemrijke dagen van de club in 1856-1857 en laat deze doorlopen tot in de jaren 1860 .

23 Bijvoorbeeld Huizinga, Heemskerk, 26.

24 E. M. Janssen Perio, 'Liberale perikelen. De liberale kiesvereniging 'Burgerplicht' te Rotterdam 18681879', Tijdschrift voor Geschiedenis, LXIX (1956) 182 (een liberale notabele in een antirevolutionaire kiesvereniging).

25 J. H. von Santen, 'Politiek leven in de stad Utrecht rond het midden van de negentiende eeuw (18401860)', Jaarboek Oud-Utrecht (1985) 137-138. Th. van Tijn, Twintig jaren Amsterdam. De maatschappelijke ontwikkeling van de hoofdstad, van de jaren '50 der vorige eeuw tot 1876 (Amsterdam, 1965) 154, toont dat nog omstreeks 1860 soms de richting van kiesverenigingen onduidelijk was. Zie, ook bij het volgende, ook L. Buning, Het herenbolwerk. Politieke en sociale terreinverkenningen in Drenthe over de periode 1748-1888 (Assen, 1966) 209, 264-266. 
gen invoerde ${ }^{26}$. In tegenstelling tot de debating societies betekende participatie in een liberale kiesvereniging toen onderschrijving van de liberale uitgangspunten. Overigens bestonden er in de praktijk onder dé vooraanstaande leden veel personele unies tussen de twee verenigingsvormen.

Het ging ondertussen in zowel debating society als kiesvereniging vooral om een gesprek tussen individuen, niet om de retorica die vereist was om brede volkslagen te mobiliseren. Weerzin tegen populisme was namelijk ook een kenmerk van liberale politiek. Van 'demagogie', van 'de volksopgewondenheid en de volksbeweging van den dag' wilden liberalen verre blijven ${ }^{27}$. Tot 1848 had het sommigen mogelijk geleken van het liberalisme een 'volksbeweging' te maken en waren de grenzen tussen hervormingsgezinde liberalen en revolutionaire radicalen niet altijd duidelijk beiden konden zijn 'van die menschen die alleen voor onrust en wanorde leven'28 daarna voerden liberalen loyale oppositie. Een overtuigde liberaal als Opzoomer wees in 1850 vooral de stijl van de radicale democraten af, getuige zijn mening dat met hun 'taal en bedoelingen geen eerlijk en vaderlandslievend man kon instemmen'29. Toen in de jaren 1860 een conservatief kabinet zich tegen de wil van de liberale kamermeerderheid wilde handhaven, schreef de liberale hoogleraar Vissering over de oppositie tegen de monarchale politiek van de conservatief Heemskerk:

Wij hebben alles vermeden wat poging tot opwinding der kiezers of van het volk achter de kiezers zou kunnen heeten. Moge maar iedereen, die zich in de kwestie mengt, zich daarvan even vrij houden! ... Zoo hebben wij gemeend onzen pligt als staatsburgers te moeten volbrengen.

Vissering wilde slechts de 'publieke opinie' voorlichten en achtte zich daartoe als staatsrechtsdeskundige in de eerste plaats geroepen ${ }^{30}$.

De liberale opvatting van politiek kon gaan domineren, omdat 'conservatieven' er nauwelijks een alternatief tegenover stelden. Ook de Nederlandse pragmatischliberale conservatieven waren niet populistisch ${ }^{31}$. Bij de verdediging van hun politiek bedienden zij zich, tenminste in de jaren 1860, van dezelfde taal als liberalen. Zij wilden in de politiek het algemeen belang behartigen en legden de nadruk op de

26 W. C. D. Olivier, Van de Stalen-Generaal (Den Haag, 1876); Vergelijk de recensie van J. Th. Buys,

De Gids (1876) iv, 157-163.

27 'Parasitische politiek', 172-173.

28 M. J. F. Robijns, Radicalen in Nederland (1840-1851) (Leiden, 1967) 201 en passim.

29 Ibidem, 298. Nog in 1881 werd de 'heftige' politieke taal van de links-liberale werkman Rot om dezelfde reden afgewezen (Helsloot, Goes, 108: citaat uit een plaatselijk dagblad, nota bene met de opmerking: 'hij mist de beschaving van den heer Domela Nieuwenhuis').

30 S. Vissering aan J. Heemskerk, 11 oktober 1866, in extenso in: Huizinga, Heemskerk, 218.

31 De uitzondering was natuurlijk de Aprilbeweging toen, 'wat zeldzaam is voor ons nationaal karakter, op straat, in koffyhuizen, in de schouwburgen, in de kerken', werkelijk overal, 'gepolitiseerd, getwist en gestreden' werd (Iz. J. Lion, Mijn staatkundig leven. Bijdrage tot de kennis der dagbladpers in Nederland (Den Haag, 1865) 35). De groep populistische groot-protestantse conservatieven was echter maar klein, en het pragmatisme van Van Hall cum suis behield de overhand. Pas in de jaren 1860 deden dergelijke conservatieven halfslachtige en niet zeer succesvolle pogingen via weerbaarheidskorpsen brede volkslagen in beweging te brengen voor hun koningsgezinde politiek (W. Bevaart, De Nederlandse defensie (1839-1874) (Den Haag, 1993)). 
'toewijding, afgescheiden van persoonlijke belangen, aan de publieke zaak' ${ }^{\prime 32}$. Tegenover het liberalisme van formele, juridische orde en een voor alle delen van het land gelijk georganiseerd bestuur, wierpen conservatieven zich zelfs op als verdedigers van de 'ware vrijheid', dat wil zeggen de oude lokale zelfstandigheid ${ }^{33}$, of van 'het ware liberalismus ${ }^{34}$. In de jaren 1860 meenden zij, evenals de liberalen, 'constitutioneel' te handelen ${ }^{35}$, merkten zij op dat juist hun zaak 'eene zaak van ernst, van beginselen, van toewijding aan de algemeene zaak' was en verweten zij op hun beurt de liberalen klein eigenbelang na te streven ${ }^{36}$. De politieke schermutselingen ontaardden in de pers en in de Kamer dan ook nogal eens in personaliteiten waarbij over en weer de goede trouw in twijfel werd getrokken ${ }^{37}$. En persoonlijke eigenschappen waren natuurlijk ook bij uitstek politiek wanneer men, met liberalen èn conservatieven, meende dat de staatkunde moest worden toevertrouwd aan mannen die daartoe door hun achtergrond, opleiding en integriteit de capaciteiten bezaten.

Liberale politiek bracht de emancipatie van bepaalde groepen met zich mee, waaronder succesvolle ondernemers, of zij die vanwege afwijkende religieuze overtuiging uitgesloten waren gebleven van politieke invloed. Bij alle onderlinge verschil betekende echter zowel de conservatieve als de liberale politiek een beperking van het politieke domein tot een elite, hetzij door traditie, afkomst en connecties, hetzij door opleiding en burgerlijke beschaving. Dit bleek vooral op lokaal niveau waarde nieuwe liberale politieke vormen vaak weinig betekenis hadden. Daarom kon omstreeks 1870 een 'verkiezingsroman' verschijnen waarin sprake was van twee partijen, de 'weigezinden' en de 'eensgezinden', die elkaar in een klein stadje bestreden met alle middelen waarover kiesverenigingen beschikten en uit naam van hoge principes. De beginselen bleken echter uitwisselbaar te zijn — beide partijen streden voor 'de algemeene belangen' en wilden 'den vooruitgang bevorderen, zonder schokken; behouden wat behouden moet worden; hervormen waar hervorming noodig is, en steeds het heil des vaderlands als rigtsnoer nemen'. Persoonlijke integriteit ging boven abstracte beginselen en in de politiek werd veel koude drukte gemaakt, zo kan men de boodschap samenvatten van het boek dat onder pseudoniem was geschreven door de hoofdredacteur van De Tijd. De recensent in De Gids kon niet ontkennen dat het boek kwaliteit bezat, maar kritiseerde toch de 'cynische minachting der menschelijke natuur' en het 'ongeloof in de kracht van het goede' die uit het boek spraken ${ }^{38}$.

32 Lion, Mijn staatkundig leven, 19. Lion was verbonden aan het conservatieve Haagse Dagblad en de belangrijkste conservatieve journalist.

33 Lion, Mijn staatkundig leven, 216-217: 'de aloude nationale vrijheid en zelfstandigheid onzer provinciën en gemeenten, tegenover den, uit de fransche revolutie tot ons overgewaaiden centralisatiegeest der Thorbeckianen'.

34 Leenders, Hoorn, 27 (1852 in de Hoornsche Courant).

35 Zie bijvoorbeeld J. van de Giessen, De opkomst van het woord democratie als leuze in Nederland (Den Haag, 1948)78-79.

36 Lion, Staatkundig leven, 107 en passim.

37 BijvoorbeeldNRC,2\.6.1873 (geciteerd door Huizinga, Heemskerk, 122): de conservatieven vormen 'een woelige, wrokkende, kwaadaardige partij, die ... een hartstochtelijke persoonlijke oppositie voert'. 38 H. van Meerbeke (- M. W. van der Aa), Zóó wordt men lid van de Tweede Kamer. Een Hollandsche verkiezingsroman (Amsterdam, 1870) 76 en passim. S. Gorter, 'De verkiezingsroman', De Gids (1870) 
Andere satires namen de liberale vormelijkheid op de hak. Het meest effectief was dat wanneer de gemaakte deftigheid van de kiesvereniging in een dorpse omgeving werd geplaatst. De niets vermoedende nieuweling die meende in een kiesvereniging waar slechts voorzitter en secretaris aanwezig waren, informeel het woord te kunnen nemen, werd terechtgewezen. Als 'vreemdeling in de parlementaire gebruiken' verschaften de beide hoogwaardigheidsbekleders hem 'een kleine opheldering' hoe 'in vergaderingen als deze het woord verkregen wordt' ${ }^{39}$. Veel nationale thema's hadden in een dorp geen rechtstreekse betekenis en het liberalisme kon dan verschijnen als een pedante doorbreking van plaatselijke patriarchale verhoudingen, 'de 'vooruitgang', in gestalte van den notaris' (in plaats van de traditionele landheer), 'nieuwerwetsch' en 'stadsch'. De notaris ontwierp dan voor de sociëteit een 'reglement' en verschafte 'hoogst fatsoenlijke lectuur, welke ons tot dusver ontbroken had, en wat zeer veel bijdroeg, om den vooruitgang op het dorp te bevorderen' ${ }^{40}$. Het was de keerzijde van de liberale opvatting van politiek en maatschappij die met haar juridisme en abstractie ouderwetse oligarchie kon doorbreken en openbaar debat en kritische zin stimuleren, maar ook tot een onvruchtbaar formalistisch spel kon leiden.

\section{Beschaafde organisatie in de jaren I860 en 1870}

De openbare sfeer van na 1848 was het domein van fatsoenlijke burgers. De verheven opvatting van publiek debat, burgerzin en algemeen belang bleef beperkt tot een minderheid. In dit opzicht was liberalisme veeleer een politiek voor de koks dan voor de gasten ${ }^{41}$. Dat liberalen er tenslotte niet in slaagden na de inrichting van de openbare sfeer ook de uitbreiding daarvan tot buiten de (gegoede) burgerij naar hun hand te zetten, had dan ook veel te maken met de vorm van liberale politiek en de stijl van liberale politici. Voordat dit duidelijk werd, hadden vooral progressieve liberalen echter ook enige successen geboekt.

Stefan Dudink heeft er op gewezen dat de linkse liberalen van de jaren 1870 het heil nog niet zozeer van de staat maar vooral van self-help verwachtten ${ }^{42}$. Zij stimuleerden de ontwikkeling van arbeiderscoöperaties als een verwezenlijking van liberale idealen. Dat 'de verbetering van den stand der arbeiders van hunne eigene werkzaamheid' en van de ontwikkeling van 'een gezonde geest van zelfvertrouwen' afhing, strookte

\footnotetext{
i, 351. Helemaal onterecht was zijn kritiek niet, want de termen van de roman — zoals 'weigezinden' en 'vooruitgang zonder schokken' - werden meer gebruikt door conservatieven dan door liberalen.

39 L. Mulder, 'De kiesvereeniging van Stellendijk' (1877), in: Idem, Dramatische werken (Den Haag, 1907) 39.

40 Mulders vriend de Oude Heer Smits (= M. Prager Lindo), 'Een gelukkig dorpje', in: Kompleete werken van den Ouden Heer Smits, L. Mulder, ed. (Den Haag, 1879) V, 204-212.

41 Deze opmerking naar analogie van een vergelijkbare verschuiving in de liberale cultuur zoals die belichaamd werd door De Gids: R. Aerts, 'De Gids en zijn publiek. Een compositieportret', Jaarboek voor Nederlandse boekgeschiedenis, I (1994) 120.

42 S. Dudink, 'Le libéralisme et la politique sociale aux Pays-Bas', in: S. Stuurman, ed., Les libéralismes, la théorie politique et l'histoire (Amsterdam, 1994) 129-135. De Engelse term was gemeengoed door een boekje van die naam van de populaire Engelse auteur Smiles. Zie over self-help en arbeidersorganisatie ook de citaten betreffende B. H. Heldt in Helsloot, Goes, 107-108.
} 
toch precies met liberale denkbeelden ${ }^{43}$ ? Sociale liberalen prezen de 'groote mate van zelfbeheersching, onafhankelijkheid, energie en zelfvertrouwen' die het besturen van coöperaties wekte ${ }^{44}$.

De coöperatie-gedachte sloot aan bij een ontwikkeling onder ambachtslieden zelf. In de jaren 1860 ontstond de ene werkliedenvereniging na de andere ${ }^{45}$. 'Ernstig vergaderen, plechtig redevoeringen houden, zorgvuldig administracie voeren' versterkten er een nieuw 'besef van eigen waardigheid'. 'De oude rederijkersidealen' herleefden hier, zoals een van de vele historici van deze vroege verenigingen wat zuinig opmerkte. Hij en andere onderzoekers schreven met al dan niet zachte spot over de vormelijkheid van de verenigingen ${ }^{46}$. Maar lag deze niet voor de hand? Zoals debating clubs liberalen oefenden in politiek, zo zetten werklieden de eerste stappen op de weg van openbaarheid en publieke betrokkenheid in hun vereniging. Met hun 'rederijkerij' volgden zij bovendien de nieuwe bloei van dit genre ${ }^{47}$.

In de jaren 1870 bleek de rederijkerij de eerste stap te zijn van politiek engagement. Toen werd namelijk uit lokale verenigingen het Algemeen Nederlandsch Werklieden Verbond gevormd en daarin kwam het tot politisering. Schaalvergroting en mobiliteit speelden hierbij een grote rol. De met de uitbreiding van het spoorwegnet vanaf de jaren 1860 toenemende mobiliteit verruimde de blik — al was de trein natuurlijk niet voor iedereen weggelegd - en de ontmoeting met standgenoten van elders leidde tot politieke bewustwording. Evenals de oudere werkliedenverenigingen huldigde de meerderheid van het ANWV een bezadigde stijl die goed aansloot bij de toon van het linkse liberalisme. Het linkse liberalisme leek in de jaren 1870 dan ook 'populair ${ }^{48}$ te kunnen worden, ook al omdat het zich profileerde op het thema van het onderwijs dat het ANWV en leden van de kleine burgerij boeide als het belangrijkste toegangsbewijs tot de beschaving die zij zochten ${ }^{49}$.

Dat het ANWV en het linkse liberalisme op de lange duur geen groot publiek mobiliseerden, was geen automatisch effect van het etiket liberalisme. Abraham

43 R. Hagoort, Patrimonium (vaderlijk erfdeel). Gedenkboek bij het gouden jubileum (Kampen, 1927) 104; hier is overigens ook sprake van 'afsmeeking van hooger zegen'.

44 S. Sr. Coronel, 'Een blik op de maatschappelijke en staatkundige ontwikkeling der arbeidende klassen in Engeland', De Gids (1869) ii, 519. Er zijn meer voorbeelden te geven, zo H. te Velde, 'H. Goeman Borgesius (1847-1917)', in: G. A. van der List, P. G. C. van Schie, ed., Van Thorbecke tot Telders. Hoofdpersonen uit de geschiedenis van het Nederlandse liberalisme vóór 1940 (Assen, 1993) 95.

45 Bijvoorbeeld B. H. Heldt, Algemeen Nederlandsch Werklieden-verbond, 1871-1896 (Leeuwarden, $18 \%)$ i; Hagoort, Patrimonium, 91.

46 D. Hudig, De vakbeweging in Nederland 1866-1878 (Amsterdam, 1904) 25. Zie ook Giele, Eerste Internationale, 22 en Rüter, Spoorwegstakingen, 45-46.

47 W. van den Berg, 'Van horen zeggen. De orale traditie in de tweede helft van de negentiende eeuw', in: J. J. Kloek, W. W. Mijnhardt, ed., De productie, distributie en consumptie van cultuur (AmsterdamAtlanta, 1991) 49-70; Idem en A. de Bruijn, 'Negentiende-eeuwse rederijkerskamers, een inventarisatie', De negentiende eeuw (1992) 163-184.

48 Van Tijn, Twintig jaren, 333.

49 Het is ook nauwelijks uit te maken of sommige van de nieuwe liberale kiesverenigingen die omstreeks 1870 her en der ontstonden, zich vormden op basis van nieuwe politieke standpunten, of als verzamelpunt voor liberalen die niet pasten in oudere verenigingen waarin gevestigde, (half-)patricische families domineerden: Janssen Perio, 'Liberale perikelen' voor Rotterdam, Van Tijn, Twintigjaren, 330-361, voor Amsterdam. 
Kuyper stak in 1874 'de vaan van het Christelijk liberalisme' op; Klaas Kater, de drijvende kracht van de antirevolutionaire afsplitsing van het ANWV Patrimonium, streed kort daarna voor 'de onbeperkte vrijheid des ge wetens ' en was ' dus liberaal, zoo liberaal mogelijk ${ }^{50}$. In Engeland, waar de verhouding tussen politiek en religie anders lag dan in Nederland en een heftiger en emotioneler toon heerste in de politieke cultuur, ontwikkelde zich een radicaal en evangelisch liberalisme, dat niet meer gebonden was aan een deftige burgercultuur 51 .

Het relatief grote succes van de tegenstanders van de Nederlandse liberalen in de komende tijd hield in de eerste plaats verband met stijl en standsbesef. De stijl van het Nederlandse liberalisme was die van intellectualistische juristen. In Engeland was de invloed van juristen minder groot $^{52}$, in Frankrijk waren er weliswaar juristen, maar dit waren veelal hartstochtelijke pleiters en meeslepende redenaars, geen afgemeten sprekers ${ }^{53}$. In Nederland werd van de antirevolutionaire jurist De Savornin Lohman gezegd dat hij laboreerde aan te grote emotionaliteit en een gebrek aan zelfbeheer$\operatorname{sing}^{54}$. Nederlandse liberalen waren geen populisten maar beheerste juristen. Zelfs onder linkse liberalen domineerde het juridische element en bevond zich geen volkstribuun: zij werden wel gekarakteriseerd als betrekkelijk 'linkse' figuren, met een zacht of zelfs onaangenaam stemgeluid dat de grote schare en zelfs het parlement niet wist te boeien. Van Houtens 'zeer zwakke stem' bezat 'geen portée, geen macht, geen wil ${ }^{155}$. Tak van Poortvliet miste 'eenige der eigenschappen, die een staatsman populair maken. Zijn vormen zijn niet gemakkelijk; zijn bondig betoog sleept niet mede; hij weet niet altijd op het juiste oogenblik zijn gedachten rondborstig te ontvouwen' $^{56}$. Eigenlijk was hij zelfs een 'ouderwetsch regent': 'Hij heeft nooit voor de kiezers willen optreden en achtte dit in strijd met onze zeden. Voor volksvergaderingen was hij de meest ongeschikte persoon ${ }^{157}$. In spreektalent stonden linkse liberalen in een Nederlandse traditie: er werd gezegd dat Thorbecke sprak 'gelijk men gewoon is in het boudoir van een zwakke kraamvrouw te doen' en volgens zijn

50 A. Kuyper, Het calvinisme, oorsprong en waarborg onzer constitutioneele vrijheden. EenNederlandsche gedachte (Amsterdam, 1874) 66; Kuyper wilde niet het 'revolutionaire Liberalisme' maar 'een Christelijk Liberalisme': Memorie van Kuyper (1874) in: Groen van Prinsterer schriflelijke nalatenschap, VII, Briefwisseling, VI, 1869-1876, J. L. van Essen, ed. (Den Haag, 1992) 736. Kater contra 'quasi liberalen' geciteerd door Hagoort, Patrimonium, 198.

51 Vergelijk S. Stuurman, 'De overwinning van de zonde. Over de verhouding russen seculiere en confessionele cultuur in de Nederlandse geschiedenis', in: P. Luykx, H. Righart, ed., Van de pastorie naar het torentje. Een eeuw confessionele politiek (Den Haag, 1991) 11-34.

52 Vergelijk S. Stuurman, Wacht op onze daden. Het liberalisme en de vernieuwing van de Nederlandse staat (Amsterdam, 1992) passim.

53 Als voorbeeld de jurist Gambetta, die als leider dreef op zijn capaciteit van hartstochtelijk strafpleiter en als zodanig ook in contact was gekomen met het 'verdrukte volk'. D. Amson, Gambetta ou le rêve brisé (Parijs, 1994) vooral 70-82.

54 Zie bijvoorbeeld L. C. Suttorp, Jhr. mr. Alexander Frederik de Savornin Lohman 1837-1924 (Den Haag, 1948)281-282.

55 F. Netscher, In en om de Tweede Kamer. Parlementaire portretten en schetsen (Amsterdam, 1889) 47. 56 'Mr. J. P. R. Tak van Poortvliet', Eigen Haard (1891) 574 geciteerd in de recente Groningse doctoraalscriptie H. Wéyers, 'Rechts en links in 1894. Tak van Poortvliet en de strijd om politieke rechten'. 57 W. H. de Beaufort, Dagboeken en aantekeningen 1874-1918, J. P. de Valk, M. van Faassen, ed. (2 dln.; 's-Gravenhage, 1993) II, 1014. 
biograaf beschikte Heemskerk overeen 'binnensmondse, schorre, brommerige stem'. Thorbecke meende op zijn beurt dat Groen van Prinsterer meer indruk zou hebben gemaakt als hij zijn schoolwet-standpunt had voorgedragen 'met het orgaan, met de houding, met de stem van Danton'. Droogjes vroeg de kamervoorzitter vervolgens Groen luider te spreken 'want bij zijne vorige redevoering is zijne stem niet geheel tot mij doorgedrongen ${ }^{\prime 58}$.

Linkse liberalen bleven betrekkelijk onwennig staan tegenover handwerkslieden en werkten vanuit het besef dat zij de dragers waren van de beschaving waartoe zij het grote publiek wilden opvoeden ${ }^{59}$. Soms deden zij in nadruk op huiselijkheid en andere brave deugden niet onder voor Biedermeier-conservatieven ${ }^{60}$. Veel liberalen realiseerden zich pas door de sociale onrust en de socialistische protesten van de jaren 1880 dat er zoiets als een volkscultuur bestond met een eigen gevoelswereld: 'Men leefde nu ja naast elkander in dezelfde stad en toch men was geheel vreemd aan elkaar' ${ }^{61}$.

Liberalen waren geen volkstribunen en wilden dat ook niet zijn. Zij deden bovendien weinig moeite zich te verplaatsen in werklieden of kleine burgers. Toetreding tot de openbare sfeer die zij hadden vormgegeven, zou alleen kunnen geschieden op hun voorwaarden. Achteraf kunnen we vaststellen dat de vormen die liberalen introduceerden in het politieke leven, zoals kiesverenigingen en debat, de basis hebben gelegd voor de via partijen georganiseerde democratische politiek. Voordat het zover was, moest echter gebroken worden met de liberale stijl. Politiek in de enge zin van het woord beschouwden grote delen van de bevolking in de negentiende eeuw als een zaak van de heren, een vorm van bestuur waartegen men zich slechts verzette - door burgerlijke woningen van vensterglas te ontdoen, zich kerkelijk af te scheiden of door andere vormen van onaangepast protest - als het de spuigaten uitliep ${ }^{62}$. Zelfs zij die het kiesrecht bezaten, waren er slechts met moeite toe te bewegen hun recht uit te oefenen en afgezien van de Aprilbeweging zijn er voor de jaren 1880 weinig

58 Het Haagse Dagblad, 9.5.1871, geciteerd door Den Hartogh, Groen van Prinsterer, 210; Huizinga, Heemskerk, 58. R. H. Bremmer, 'Groen en Thorbecke', in: C. Bremmer, M. N. G. Kool, ed., Een staatsman ter navolging. Groen van Prinsterer herdacht (1876-1976) (Den Haag, 1976) 82. Vergelijkbare kritiek was er ook op veel andere politici.

59 Zie bijvoorbeeld de paternalistische toon over zijn werk als commissaris van een coöperatieve sigarenmakersvereniging in H. Goeman Borgesius aan B. D. H. Teilegen, 11.9 [ 1871 ], archief-Tellegen, Algemeen Rijksarchief Den Haag, inv. nr. 149: citaat bij Te Velde, 'Goeman Borgesius', 96.

60 Zo in de steun van lieden als Kerdijk, Pekelharing en andere linkse liberalen aan 'Floralia', een vereniging die arbeiders wilde beschaven door ze het genot van het kweken van plantjes bij te brengen: J. Helsloot, Floralia in Nederland in het laatste kwart van de negentiende eeuw (Amsterdam, 1990) 32 en passim.

61 A. Pierson, na zijn ervaring van een 'volks vergadering' waar hij zich over het hoge niveau en de liefde voor Domela had verbaasd: F. Domela Nieuwenhuis, Van christen tot anarchist. Gedenkschriften (Amsterdam, s. a.) 203-204. Zie ook De Amsterdammer, 15 augustus 1886 naar aanleiding van het Palingoproer (citaat bij H. te Velde, Gemeenschapszin en plichtsbesef. Liberalisme en nationalisme in Nederland, 1870-1918 (Den Haag, 1992) 127).

62 De Rooy, 'Zes studies over verzuiling', makt hier verhelderende opmerkingen over. Hij verwijst naar Leenders, Hoorn, 330-331, als ondersteuning voor de stelling dat politiek als bestuur werd opgevat waaraan men zich normaal gesproken onderwierp. De protesten vindt hij in Giele, Eerste Internationale; ook bijvoorbeeld in Robijns, Radicalen, kan men er voorbeelden van vinden, maar er zouden gemakkelijk meer te geven zijn. 
voorbeelden te noemen van buitenparlementaire politieke agitatie op grote schaal. Wie tevreden was over de gang van zaken, liet zich niet in met politiek, wie ontevreden was, voelde zich niet aangesproken door de liberale vorm van politiek die in zijn stijl nauw aansloot bij de negentiende-eeuwse standenstructuur. Het kostte de links-liberale leider van het ANWV B. H. Heldt daarom moeite zich te verweren tegen het verwijt dat hij de slippendrager van de heren was. Grotere toegankelijkheid van de openbaarheid verlangde een nieuwe toon. Deze werd onder meer aangeslagen door de antirevolutionaire minderheid die zich onder de naam Patrimonium van het inmiddels uitgesproken liberale ANWV afscheidde.

\section{Onfatsoen, mobilisatie en 'lyrisch' leiderschap in de jaren 1880}

Doctrinaire liberalen hadden politiek willen maken tot een debat over het algemeen belang, op parlementaire toon gevoerd. Werklieden konden daaraan deelnemen als zij in staat zouden zijn hun eigenbelang te vergeten in 'toewijding, deugd en nog eens deugd' en 'de verplichting' zouden 'aanvaarden niet om te draaien rondom eigen as maar rondom de groote spil van het algemeen belang' ${ }^{\prime 63}$. Zij moesten leren te abstraheren van hun verlangens en identiteit. In de jaren 1880 veranderde de politieke retorica echter. Er ontstond een politiek die juist appelleerde aan gevoelens en kwesties die nauw met (levensbeschouwelijke) identiteit verbonden waren. Dit is te verduidelijken aan de hand van twee groepen die zich omstreeks 1880 in politieke organisaties manifesteerden: antirevolutionairen en socialisten. Zij riepen gereformeerden en geschoolde werklieden toe dat zij de kern van de natie vormden en hun opvattingen naar voren dienden te brengen in de politiek. Zij maakten gebruik van de mogelijkheden die de door de liberalen geschapen openbare sfeer bood, maar hun succes was pas mogelijk nadat ze braken met de liberale vorm van politiek: in thematiek, maar vooral in stijl.

De werkwijze van de twee politieke groepen vertoonde overeenkomsten. Zij sneden thema's aan die appelleerden aan de gevoelens en identiteit van het volk achter de kiezers. Allereerst ging het dan natuurlijk om orthodox geloof en sociale misère, maar ook 'de natie' kreeg nieuwe gevoelswaarde en politieke betekenis. Zo liep Patrimonium vooraan in het op Transvaal gerichte nationalisme dat Nederland in de jaren 1880 in zijn greep hield ${ }^{64}$. Dit nationalisme was voor Patrimonium als jonge levensbeschouwelijke organisatie een uitgezochte gelegenheid haar bestaansrecht te bewijzen. De band met de eenvoudige calvinistische Boeren bevestigde het levensbeschouwelijk stempel van Patrimonium, versterkte de saamhorigheid onder de leden en maakte het mogelijk zich te manifesteren als een organisatie die zowel de christelijke principes als het Nederlands nationaal gevoel hooghield ${ }^{65}$. Het Transvaal-nationalisme bevatte een

63 J. Th. Buys, 'Onze aanstaande reformbill', De Gids (1882) i, 330.

64 Kuyper sprak in 1884 op uitnodiging van Patrimonium in de Amsterdamse zaal Plancius de Transvaalse deputatie toe die in Nederland verbleef. De Plancius-rede wordt in de uitvoerige Zuid-Afrikaliteratuur meermalen behandeld, maar aan de rol van Patrimonium wordt nauwelijks aandacht geschonken. Het gedenkboek Hagoort, Patrimonium, wijdt er echter bijna twintig pagina's aan.

65 In dit opzicht was het bezoek van de Boeren een katalysator voor Patrimonium zoals de reis van 
radicaal element dat niet rechtstreeks tot politieke polarisatie of sociale onrust leidde. Dit nationalisme kon het antirevolutionaire alternatief zijn voor het met de socialisten geassocieerde maatschappelijke protest. Zo kon Patrimonium Kuyper aan zich bin$\operatorname{den}^{66}$ en zich openbaar onderscheiden van het algemeen-belang-met-vaderlandsliefde van het ANWV en van de in de SDB populaire radicaal-Jacobijnse voorstelling van een werkelijk nationale politiek ${ }^{67}$. Zo was ook een emotievolle, mobiliserende en met levensbeschouwelijke identiteit verbonden variant van het algemeen belang gevonden.

Ook sommige conservatieve liberalen sneden nu nieuwe thema's aan in de hoop het volk te mobiliseren. Zij deden een beroep op de monarchie en haar symbolische kracht. Er bestond tot dan toe geen sterk populistisch monarchaal conservatisme met steun in de volksklasse - al speelde in vroege politieke uitingen buiten het bestaande politiek bestel de gedachte van de 'goede koning' een rol en treft men naklanken daarvan nog tot in de jaren $1870 \mathrm{aan}^{68}$. In de jaren tachtig en negentig was Oranje een troef in handen van een burgerlijk en behoudend liberalisme. De houding van socialisten werd toen ondubbelzinnig antimonarchaal en de afstand van een antirevolutionair als Kuyper tot de monarchie was veel groter dan dié van de oudere groot-protestantse conservatieven.

De gevoelswaarde van hun thema's buitten socialisten en antirevolutionairen uit met een heftiger retoriek en een veel grotere emotionele intensiteit dan liberalen in hun politieke werk plachten te leggen. Al vroeg hadden liberalen antirevolutionairen verweten te 'spekuleren op de hartstogten des volks' en 'teksten' en 'de tale Kanaans' te gebruiken in plaats van 'argumenten' ${ }^{69}$. Ook revolutionaire socialisten zaaiden volgens hen 'haat en tweedracht' en prikkelden 'de booze hartstochten der menschen ${ }^{70}$. Socialisten zelf meenden dat het op 'burgerlijke congressen' slechts ging om 'berekening' en dat het niet te verwonderen was dat 'onder strijdende arbeiders die heel hun leven aan den strijd' gaven, 'de vlammen er eens uit vlogen' ${ }^{71}$.

De nieuwe retorica was vooral een wapen in handen van de politieke leiders. Het politieke leiderschap was een cruciale factor in de uitbreiding van de openbaarheid. 'Heren' dienden het goede liberale voorbeeld te geven, maar nu gebeurde het omgekeerde. 'Wanneer beschaafde lieden revolutie maken wordt het volk bandeloos' merkte een bedaagde liberale notabele op naar aanleiding van Kuypers optreden ${ }^{72}$. De

Garibaldi naar Engeland in 1864 voor radicaal-liberale Engelse arbeiders was geweest: Biagini, Liberty, 372-375

66 Hagoort, Patrimonium, 268.

67 Vergelijk het nog ongepubliceerde S. Dudink, 'Het vervliegen van de gemeenschap. Sociaal-liberalen, politieke openbaarheid en de staat 1880-1900'.

68 Men zie de voortdurende dubbelzinnigheid in de houding tegenover de koning van radicalen als Van Bevervoorde bij Robijns, Radicalen; Giele, Eerste Internationale, 224,247 geeft voorbeelden uit 1873 en 1877; ook onaangepaste intellectuelen als Busken Huet en Multatuli speelden met ondoordachte plannen over versterking van de positie van de vorst.

69 Prov. Friesche Courant, 12.6.1864, geciteerd door G, Abma, Geloof en politiek. Confessionele partijvorming in Friesland. Ontstaan en eerste jaren (1852-1871) (Leeuwarden, 1980) 278-279.

70 'Ons eerste woord', Sociaal Weekblad, 1 ( 1887) 1, als één voorbeeld uit vele.

71 Citaat van Polak uit 1901 bij S. Bloemgarten, Henri Polak sociaal democraat 1868-1943 (Den Haag, 1993) 232.

72 De Beaufort, Dagboeken, 1,26. Altena, Vlissingen, wijst ook op de verontwaardiging jegens deserterende heren. 
lyriek die met de tachtigers in de literatuur zou doorbreken, bezielde ook Kuyper, Domela en Troelstra. Hun emotionaliteit werd als 'echt' beleefd en riep juist daarom bij hun achterban een gevoelvolle respons op. Linkse liberalen hadden al opgemerkt dat de kleine burgerij 'bij voorkeur aan iemand, die boven haar staat in maatschappelijke rang de macht in handen geven' wilde, maar het moest wel iemand zijn die 'haar vertrouwen verdient ${ }^{73}$. Voor dat vertrouwen was bestuurlijke integriteit niet voldoende, maar was ook emotionele en levensbeschouwelijke betrokkenheid van politiek leiders vereist. Door de verbondenheid was de afstand tussen politicus en achterban klein zodat deze laatste een actieve rol kon spelen. 'Ik was in de arbeidersbeweging getrokken, hoe weet ik nog niet, maar ik stond er midden in voordat ik het wist' schreef Domela in een bekende passage ${ }^{74}$. En het antirevolutionaire werkliedenverbond Patrimonium ontstond niet door het werk van Kuyper, zoals het later wel eens werd voorgesteld, maar het verbond zocht juist Kuyper op ${ }^{75}$. Anderzijds was de afstand juist groot, omdat het sociale verschil tussen leider en aanhang, dat voorheen minimaal was toen politiek iets was van een sociaal veel homogener groep, nu veel groter werd. Het was juist de combinatie van afstand en nabijheid en de spanning die daardoor optrad die het charisma van de leiders bepaalde: de (emotionele en levensbeschouwelijke) betrokkenheid was groot maar de (sociale) afstand bepaalde dat het voetstuk dat voor charisma onontbeerlijk is, intact bleef ${ }^{76}$.

De stijl van de nieuwe leider verzette zich tegen het conservatieve en liberale paternalisme, maar was op een andere manier ook paternalistisch. Kuyper, Domela Nieuwenhuis en Troelstra wezen hun volgelingen de weg. Domela streed voor de emancipatie van de arbeider en zijn 'doel en streven was', zoals hij later schreef, 'om mij als leider overbodig te maken evenals dit het geval moet zijn bij de opvoeding der kinderen door verstandige ouders ${ }^{77}$, maar daarmee verklaarde hij voor zolang als het duurde de arbeiders wel tot onvolwassenen die begeleiding behoefden. Liberale politiek was het debat tussen gelijken; de nieuwe politiek was de enthousiasmerende preek of rede die opwekte tot aansluiting en een gevoel van verbondenheid opriep.

Naast thematiek, retoriek en leiderschap was er de stijl van openbaar optreden. De politiek werd minder fatsoenlijk. Deftige christelijk-historische voormannen als De Savornin Lohman en Talma beschouwden zichzelf als 'volksman—geen 'fatsoenlijk burger" en haatten 'de plutocratie en de fatsoenlijkheid ${ }^{78}$. De liberale beschaving was hun te lauw, te vormelijk en te weinig geïnspireerd. Domela's aanhang dacht er net zo

\footnotetext{
73 Manifest van de links-liberale Amsterdamse kiesvereniging Burgerplicht: Van Tijn, Twintig jaren, 331 .

74 Domela Nieuwenhuis, Van christen tot anarchist, 54 (cursivering toegevoegd).

75 Zoals Hagoort, Patrimonium benadrukt.

76 Vergelijk H. te Velde, 'Natievorming en politieke strijd in Nederland', Beleid en Maatschappij ( 1995) 104 met een citaat van de sociaal-democraat W. H. Vliegen. Dit neemt niet weg dat rationalistische, leerstellige theorie of theologie voor antirevolutionairen en (later) socialisten een grote rol speelde.

77 Domela Nieuwenhuis, Van christen tot anarchist, 390.

78 Brief van De Savomin Lohman aan Kuyper, 29:4.1875, geciteerd in P. Kasteel, Abraham Kuyper (Kampen, 1938) 106 (wel voegde hij eraan toe: 'Ons volk is te veel gerevolutioneerd, dan dat men er niet voorzichtig mee zou moeten omgaan. Niet allen zijn Kattenburgers! '); A. S. Talma geciteerd door Altena, Vlissingen, 153.
} 
over. Socialisten stoorden zich niet aan de fatsoensgrenzen die de liberale politiek hoog in het vaandel droeg en hielden zich bezig met colporteren dat voor 'onfatsoenlijk' doorging $^{79}$. Zij overwogen ook in navolging van overtuigde protestanten te gaan evangeliseren op de hoek van de straat ${ }^{80}$. Zoals de antirevolutionairen methoden van politiek en agitatie soms afkeken van het overtuigd protestantse Engelse liberalisme, zo spiegelden socialisten zich op hun beurt soms aan protestantse bekeringsmethoden. De toon van het politieke leven was heftiger geworden en Domela had er geen bezwaar tegen: 'In revolutionaire tijdvakken heeft men te doen met allerlei slag van menschen, dikwijls met hen die men in 'fatsoenlijk' gezelschap liefst zou verwijderen' ${ }^{81}$.

De SDB en de antirevolutionairen namen in de jaren 1880 afstand tot de bezadigde burgercultuur en het verbaast niet dat sommigen toen pendelden tussen Patrimonium, SDB en het ietwat geëxalteerde, uit Engeland overgewaaide Leger des Heils ${ }^{82}$. De stijl van socialisten en antirevolutionairen week af van de stijl van liberalen en conservatieven uit de voorafgaande periode. Zij week ook af van wat later gebruikelijk zou worden, toen een sociaal-democraat als Polak zijn aanhang 'goede organisatiebegrippen' wilde bijbrengen en leren hoe 'een fatsoenlijk mensch en bewust arbeider behoort te doen ${ }^{183}$. Onder invloed van de tegenstelling tussen goed georganiseerde sociaal-democraten en communisten enerzijds en anarchisten anderzijds is het verschil later wel voorgesteld als een kinderziekte van de socialistische beweging. Er zouden dan twee stromingen bestaan:

De een die, waarschijnlijk het ernstigst van kommunistisch geloof bezield, stevigen opbouw verlangde, vaste organizeering, mannen die naast ruimte van blik hollandsche degelijkheid bezaten. De tweede, de schreeuwers, lui met een luidruchtig temperament, wildemannen met avontuurlijken aanleg.

Onder die laatste categorie bevonden zich ook wel 'goede drinkers' ${ }^{84}$. Op deze manier ontstaat een te antropomorf beeld van politieke stromingen: na een onbezonnen jeugd zou dan een serieuze volwassenheid volgen, na de harde 'leerschool der ontgoocheling' sloeg de arbeidersbeweging 'den weg naarde werkelijkheid' in ${ }^{85}$. De hier besproken fase was echter een essentiële stap in de verandering van het politieke leven. Pas toen nieuwe politieke bewegingen braken met de 'fatsoenlijke' politieke stijl, kon politiek iets worden waarbij ook zij zich betrokken voelden die niet behoorden tot de

79 Domela, Van christen tot anarchist, 100 over'gezeten arbeiders' die 'op straat' gingen 'kolporteeren': 'In den Haag, waar het uiterlijk fatsoen heerschte tot in de arbeidersklasse toe, achtte men zoiets onfatsoenlijk'.

80 J. Charité, De Sociaal-Democratische Bond als orde- en gezagsprobleem voor de overheid (18801888) (Hen Haag, 1972)31.

81 Domela Nieuwenhuis, Van christen tot anarchist, 368. Antirevolutionairen verzetten zich tegen het fatsoen in levensbeschouwing en mentaliteit, niet in het maatschappelijk verkeer. Vergelijk A. Kuyper, De Christus en de sociale nooden en democratische klippen (Amsterdam, 1895) 84: 'De belijdenis van den Christus maakt ook den minderen man beleefd en fatsoenlijk'.

82 Men zie bijvoorbeeld de opmerkingen bij Helsloot, Goes, 251.

83 Citaat (1909) in Bloemgarten, Polak, 359-360.

84 Hudig, Vakbeweging, 29-30 (een commentaar op de vroege Internationale).

85 Hoofdstuktitels van Rüter, Spoorwegstakingen. 
elite van kiezers. Pas nadat sociaal-democraten en antirevolutionairen het bestaande politieke systeem opengebroken hadden, konden zij parlement, kiesvereniging, debat en openbaarheid optimaal voor eigen doeleinden gebruiken.

\section{Gepassioneerde politiek, beginselen en organisatie}

De groei van goed georganiseerde politieke partijen sprak niet vanzelf maar veronderstelde een ingrijpende verandering van de liberale openbaarheid. Het abstracte beroep op het algemeen belang maakte plaats voor een politiek waarin ruimte was voor passie en identiteit. Het hoogtepunt van de ermee gepaard gaande onrust lag in de tweede helft van de jaren $1880^{86}$ met een uitloop in de jaren $1890^{87}$. Voor Kuyper waren de jaren 1880 achteraf 'de periode van heilige geestdrift'. 'Het was een heerlijke tijd. Een tijd die aantrok en verkwikte. Het werd een warme aaneensluiting der broederen ${ }^{\prime 88}$. 'Men gevoelde zich niet in naam maar in werkelijkheid broeders', schreef ook Domela. 'Men hielp elkaar, men verrichtte alle propagandawerk samen'; deze jaren waren 'de schoonste der socialistische beweging' ${ }^{\prime 89}$.

In deze jaren veranderde om te beginnen het fysieke karakter van de openbaarheid: het politieke enthousiasme manifesteerde zich nu op straat. Al in de jaren veertig waren er pogingen ondernomen om politieke demonstraties op touw te zetten, maar die waren in halve mislukkingen blijven steken; toen hadden de radicalen 'de pen in de aanslag', maar het bleef bij protest op papier ${ }^{90}$. Straatprotest was er wel, maar dat werd niet als 'politiek' beschouwd. Omstreeks 1870 kon men als vanzelfsprekend opmerken dat er in Nederland geen 'optogten en meetings' waren als in Engeland:

Ginds gedruisch, volksbewegingen, razen en tieren en somtijds kloppartijen; hier geen dezer ergelijke tooneelen. Alles gaat even bedaard en kalm in zijn werk als altoos. De rustige aard onzer landgenooten verloochent zich ook niet in dagen van politieke spanning 91 .

En in 1877 heette het zelfs: 'een inwoner van ons koud en redeneerend vaderland met een roode vlag in de hand is bijna een even groote anomalie als een bewoner der keerkringen op schaatsen' ${ }^{12}$. In de jaren tachtig was dat veranderd. De publieke sfeer werd nu uitgebreid naar de straat, een terrein ver verwijderd van parlementaire stijl en gecultiveerde debatvereniging.

\footnotetext{
86 Vergelijk Domela Nieuwenhuis, Van christen tol anarchist, 130: 'De jaren 1886 en 87 waren voor mij en ook voor de geheele sociaaldemokratische partij de woeligste die wij beleefden'.

87 De rel tussen SDB en SDAP in 1894 in de Amsterdamse zaal Constantia behoort nog tot deze periode, in de zin dat sociaal-democraten achteraf de anarchisten tot herrieschoppers bestempelden, maar de confrontatie op dat moment een wezenlijk politieke betekenis had: de SDAP kreeg voorlopig geen voet aan de grond in Amsterdam (H. Buiting, Richtingen- en partijstrijd in de SDAP. Het ontstaan van de Sociaal- Democratische Partij in Nederland (Amsterdam, 1989) 37-38). Zie voor een botsing tussen SDAP-ers en 'Socialistenbonders' in 1896 in Plancius: Bloemgarten, Polak, 191.

88 A. Kuyper, Starrentritsen. Editio castigata (Kampen, 1915) 20-21.

89 Domela Nieuwenhuis, Van christen tol anarchist, 100, 102.

90 Robijns, Radicalen, 2; J. J. Giele, De pen in aanslag. Revolutionairen rond 1848 (Bussum, 1968).

91 Van Meerbeke, Lid van de Tweede Kamer, 294.

92 W. J. N. Landré, 'Twee kamerleden', Het leeskabinet (Mil) 49; de zinsnede is een geniststelling dat de twee Kamerleden Van Houten en Kappeyne niet werkelijk rode radicalen zijn.
} 
De socialisten manifesteerden zich met nationale toogdagen ${ }^{93}$ en met de grote kiesrechtdemonstraties van deze jaren, die overigens bij gebrek aan een nationale traditie op dit terrein in symboliek en taalgebruik aansluiting zochten bij de Franse Revolutie $^{94}$. Ze hielden er ook een eigen vergaderstijl op na. Ook zij kenden hun vergadertraining die zij soms zelfs debating club noemden, maar het doel ervan was anders dan voor liberalen: geen oefening in onderling gesprek, het ging er nu vooral om een groot publiek te pakken en het socialistische beginsel publiek te verdedigen tegen andersdenkenden, desnoods met ketelmuziek ${ }^{95}$. Ook in de vergaderzaal veranderde er veel. Voortdurend namen luidruchtige sociaal-democraten bijeenkomsten van andere groeperingen over, van de liberale vereniging Volksonderwijs, maar vooral van het brave ANWV waarvan de leden 'tegen die weldoordachte wijze van beweging maken niet opgewassen' waren ${ }^{96}$. Het strijdbare antirevolutionaire Patrimonium was er naar het schijnt beter tegen bestand ${ }^{97}$.

Uiteindelijk zouden de nieuwe politieke vergaderingen dezelfde ontwikkeling doormaken als de vroege kiesverenigingen. Na een fase waarin ze open stonden voor debat - het beroemde debat van Treub met de sociaal-democraten uit $1891^{98}$ is er een duidelijk voorbeeld van - veranderden ze in bijeenkomsten van gelijkgestemden die meningsverschillen niet langer met tegenstanders maar onderling uitvochten ${ }^{99}$. Op den duur was er nog slechts in verkiezingstijd debat met andersdenkenden ${ }^{100}$. De partijbeginselen dienden als een middel om de schapen - met wie men als partijgenoot overlegde - te scheiden van de bokken - tegen wie men slechts polemiseerde. De wij-groep werd gevormd door de aanhangers van de juiste beginselen, 'zij' waren de anderen, de opportunisten, trouwelozen of door het verkeerde uitgangspunt verblinden.

Voor een partij als de ARP waren de beginselen alles. Kuyper was zich ervan bewust dat niet alleen zijn strijdmethoden maar zelfs zijn verlangens enige overeenkomsten vertoonden met die van 'de radicalen der linkerzij ' ${ }^{101}$. Des te belangrijker was het zich op het punt van de beginselen van hen te onderscheiden. De beginselen konden

\section{Charité, Sociaal-Democratische Bond, 60-61.}

94 De Jacobijnse retoriek wordt in de literatuur op veel plaatsen besproken; de Patriottenbeweging was te zeer een afgesloten verleden om als inspiratiebron te dienen. Een oudliberaal commentator merkte op: 'Het pleit niet voor de oorspronkelijkheid en frischheid der verbeelding onzer democraten, wanneer zij hun zinnebeelden en veldteekens gaan zoeken in een grafgewelf, onder de stoffige reliquien van de Fransche revolutie', J. H. Hooyer, 'Een vrouw fin de siècle. Madame du Deffand', De Gids (1891) iv, 382.

95 G. Bruintjes, Socialisme in Groningen 1881-1894 (Amsterdam, 1981) 31, 41, 50, 94.

96 Heldt, $A N W V$, 58,70-71 ; citaat van 71 ; dit citaat ook bij Rüter, Spoorwegstakingen, 10. Domela, Van christen tot anarchist, 94. Een vroeg voorbeeld (1876) bij Giele, Internationale, 247. In 1890 achtervolgde de socialist Schaper Heldt op zijn spreektoumee door de provincie Groningen: Bruintjes, Socialisme in Groningen, 60-61.

97 Charité, Sociaal-Democratische Bond, 33.

98 M. W. F. Treub, De radicalen tegenover de sociaal-democratische partij in Nederland. Voordracht gehouden op maandag 26 januari 1891 in de afdeeling Amsterdam van den Sociaal-Democratischen Bond (Amsterdam, 1891).

99 Drs. Homme Wedman maakte ons attent op deze eigenaardigheid.

100 F. M. Wibaut, Levensbouw. Memoires (Amsterdam, 1936) onder meer 151.

101 Kuyper, Calvinisme, 66. 
bovendien de strijdmethoden legitimeren die in de liberale wereld voor onfatsoenlijk doorgingen en paalden het politieke terrein op een nieuwe manier af, nu politiek niet meer als vanzelfsprekend het domein was van een bepaalde sociale groep ${ }^{102}$. Daar kwam dan nog bij dat Kuypers potentiële achterban leed aan 'politicophobie' en ervan overtuigd moest worden dat antirevolutionaire politiek iets anders was dan ordinaire machtsstrijd of bestuurlijk opportunisme. Antirevolutionairen plaatsten dus hun getuigenis- of beginselpolitiek tegenover politiek marchanderen oftewel hun 'politiek der hoogere sferen, tegenover 'de politiek der lagere sferen', die haar getuigenis afhankelijk stelt van becijfering en omstandigheden ${ }^{\prime 103}$. Iets dergelijks vindt men ook in socialistische kring; bijvoorbeeld inTroelstra's hartekreetdat voor hem 'de politiek groot en hoog' was en dat hij daarin kon 'uiten het beste, wat in mij is ${ }^{104}$. Deze vorm van hoge politiek stond of viel met tot een programma uitgewerkte beginselen. Kuyper verzette zich dus tegen 'de potsierlijke voorstelling, als ware de schoolquaestie het eenig stuk op ons répertoire' en trachtte in Ons Program te tonen dat de antirevolutionaire beginselen op alle terreinen van politiek en leven van betekenis waren ${ }^{105}$.

Beginselen stroomlijnden ook de vorming van politieke organisaties. Terwijl het ANWV een bundeling van lokale verenigingen was die geleidelijk een politieke identiteit verkreeg, kon Patrimonium door het toegenomen belang van ideologische uitgangspunten gesticht worden als expliciet antirevolutionaire, landelijke vereniging, waarbij zich daarna lokale afdelingen aansloten. Om problemen met SDB-ers te voorkomen, wilde men bij de oprichting van de SDAP alleen hen toelaten die de beginselen hadden ondertekend ${ }^{106}$. In socialistische kring zou vervolgens de mate en wijze van centrale organisatie een van de belangrijkste verschillen worden tussen SDB en SDAP $^{107}$ en hetzelfde gold voor de 'georganiseerde' ARP tegenover de vrij-antirevolutionairen van Lohman ${ }^{108}$.

\section{Partijvorming, zakelijkheid en staatsbestuur}

Met de vestiging van de 'georganiseerde' ARP en SDAP vormde zich de trias van beginselen, organisatie en politieke leiding ${ }^{109}$. Toen deze vanzelfsprekend werd, raak-

\footnotetext{
102 Ook socialisten legden de nadruk op 'beginselen' (bijvoorbeeld Bruintjes, Socialisme in Groningen, 29). Deze werden later dan weer een dwangbuis waartegen Troelstra zich verzette als 'het tot dogma verheven 'beginsel" (bijvoorbeeld Buiting, Richtingen- en partijstrijd, 283).

103 Den Hartogh, Groen, 234; zie ook 104.

104 Uitspraak van Troelstra in de Kamer (1909), nota bene (in de lintjesaffaire) tegen Kuyper, geciteerd in Idem, Gedenkschriften, III (Amsterdam, 1929) 151.

105 J. H. Prins, 'Kuyper als partijleider', in: Idem, C. Augustijn, H. E. S. Woldring, ed., Abraham Kuyper. Zijn volksdeel, zijn invloed (Delft, 1987) 99. Op dit punt verschilde hij van Groen, die wel beginselen maar geen uitgewerkt progTam wenste.

$106 \mathrm{Na}$ tien jaren. Gedenkschrift bij het tienjarig bestaan der Sociaal-Democratische Arbeiderspartij (Amsterdam, 1904) 7.

107 Zie J. Perry in Idem, e. a., Honderd jaar sociaal-democratie in Nederland 1894-1994 (Amsterdam, 1994) 23 en 24 en P. de Rooy, 'Begeerten en idealen. Een eeuw sociaal-democratie in Nederland', in: Idem, e. a., De rode droom. Een eeuw sociaal-democratie in Nederland (Nijmegen, 1995) 21.

108 Zie A. F. de Savornin Lohman, Bijdragen lot de geschiedenis der Christelijk-Historische Unie, $\mathrm{H}$. van Malsen, ed. (2 dln.; Den Haag, 1932).

109 De breuk van 1894 was in beide gevallen essentieel.
} 
ten de emotiegeladen retoriek, het nieuwe leiderschap en de 'onfatsoenlijke' stijl van de jaren 1880 onder invloed van de eisen die partij- en staatsbestuur stelden weer op de achtergrond. In deze periode werd de inrichting en werking van de openbaarheid steeds meer vanuit de staat beïnvloed. De openbaarheid die aan het eind van de eeuw ontstond, was zowel het produkt van de vorming van beginselpartijen, als van de groei van het staatsingrijpen.

Sociaal-democraten, maar ook antirevolutionairen en katholieken stuitten al snel op de grenzen van het ideologische enthousiasme. Die lagen niet zozeer bij de geldigheid van de beginselen, als wel bij de verhouding tussen beginsel en politieke praktijk. Sociaal-democraten werden voortdurend heen en weer geslingerd tussen radicale verwachtingen en bescheiden mogelijkheden, terwijl vooraanstaande anti-revolutionairen opmerkten dat beginselen niet voldoende houvast gaven bij de concrete vragen die zij in het parlementaire werk moesten beantwoorden: 'Wij weten op tal van punten niet, waar we aan toe zijn, welke de draagkracht en de straallengte van onze beginselen is, welken kant we uit moeten sturen' ${ }^{110}$. Dit bracht een verandering van politieke stijl met zich mee die ook de katholieken raakte. Schaepman merkte op:

Mijn tijdgenoten en ik hebben vrij wat aan sociale retorica gedaan. Maar wat in die dagen gelden kon, geldt nu niet meer. Er zijn andere dingen aan de orde en die andere dingen vorderen een andere stijl. De lyrisch-retorische voordrachten hebben haar tijd gehad' 111.

Hierin lag volgens hem het onderscheid met zijn opvolger, Nolens, die hij prees als 'de wetenschappelijkste onderde katholieke sociologen'. In de jaren twintig bevestigde Aalberse:

Thans gaat het over de concrete, praktische toepassing van beginselen, en moeizaam geduldig opbouwen, steentje voor steentje, en kennis van velerlei details, en afwegen van grote, maar vooral van vele kleine belangen. In deze tijd heeft Nolens ons gegeven wat van Schaepman niet verwacht had kunnen worden' ${ }^{112}$.

Het onderscheid tussen Schaepman en Nolens geeft al aan, dat niet alleen de rol van beginselen, maar ook die van de politieke leiding omstreeks 1900 veranderde. Zowel in de SDAP als in de ARP manifesteerde zich na 1900 een leiderschapscrisis' ${ }^{113}$. Op het moment dat de partijorganisatie vaste vorm kreeg en niet langer voortdurend door de mobiliserende retoriek van de leiding bij elkaar gehouden hoefde te worden, ontstond er tussen organisatie en leiding een spanning. De leider was niet meer de vanzelfsprekende verpersoonlijking van de partij, de onaantastbare figuur om wie zich de aanhang

110 A. Anema, e. a., Leider en leiding in de Anti-revolutionaire partij (Amsterdam, 1915) 45.

111 Schaepman in Chronica voor Staatkunde en Letteren, III, (1902) i, 5-6, geciteerd in J. P. Gribling, Willem Hubertus Nolens I860-1931. Uit het leven van een priester-staatsman (Assen, 1987) 109.

112 Aalberse in Dr. Nolens (1927) 9, geciteerd in Gribling, Nolens, 110.

113 Zie Anema, e. a., Leider en leiding en Kuyper, Starrentritsen over Kuypers leiderschap, en F. van der Goes, Verkeerde partijleiding (Rotterdam, 1907) en P. J. Troelstra, Inzake partijleiding. Toelichtingen en gegevens (Rotterdam, 1906) over dat van Troelstra; vergelijk Buiting, Richtingen- en partijstrijd, onder meer 280-293 en 362 . 
verzamelde. De leider moest nu leiden naar eigen inzicht maar ook in overeenstemming met de partij. Op paradoxale wijze deden zowel Troelstra als Kuyper nu een beroep op het 'vertrouwen' dat zij verdienden ${ }^{114}$. Troelstra wilde volgens Van der Goes 'het ongerijmde: hij wil 'vertrouwd' worden omdat hij de leider is' ${ }^{115}$. Het leiderschap was echter geen mysterieuze kwaliteit van een persoon maar 'een opdracht gegeven aan hem wiens meningen de meeste instemming vinden'.

Aan het begin van de twintigste eeuw ontstond een nieuw soort politicus, die op het eerste gezicht veel weg had van de bedachtzame liberaal van 1848. Zijn vaardigheid berustte niet op retorische vaardigheden, maar vooral op het vermogen om verantwoordelijke beslissingen te nemen. Zo schetste een feestredenaar bij het vijfentwintigjarig jubileum van Albarda als Kamerlid in 1938 een drietal fasen van leider en leiding. De eerste fase was die van de 'verklanking' van het leed in fabrieken en werkplaatsen, waarvoor de predikant Domela Nieuwenhuis geschikt was geweest. In de tweede fase speelde het gevoel nog steeds een grote rol, maar had men in de voorste gelederen van de beweging te letten op de gegroeide verantwoordelijkheid in openbare lichamen. Dit was in goede handen bij de advocaat Troelstra. Ten slotte werd in een derde fase de overgang gemaakt van oppositie naar constructie, waarin concrete plannen vereist waren, die het best gemaakt konden worden door de ingenieur Albarda ${ }^{116}$.

Dit schema is al te mooi. Enerzijds bleven verschillende typen politici enige tijd naast elkaar bestaan, anderzijds hing de geschetste verschuiving in leiderschap natuurlijk ook af van de beschikbaarheid van geschikte personen. Toch bracht het nieuwe, 'constructieve ' leiderschap een nieuw element in de politieke stijl. Naast het bloemrijk taalgebruik van Troelstra kwam nu ook een drogere stijl. Volgens Vliegen was Albarda's beperkte retorische begaafdheid geen bezwaar. Want behalve dat Troelstra vaak te lang van stof was, ging het in het parlementaire werk om

zakelijke argumenten. Het is daar een nuchter gezelschap. Alleen wanneer duidelijke feiten ten grondslag liggen aan gevoelsuitingen, worden deze geaccepteerd, en dan nog. Feiten die den socialist in het diepst van zijn ziel zullen krenken, laten vaak den antirevolutionnair of den liberaal steenkoud. De papieren van het pathos staan er gewoonlijk ver beneden pari ${ }^{117}$.

De drogere stijl betekende echter niet dat het beroep op de sentimenten van de achterban achterwege bleef. Integendeel: na 1880 kregen verlangens en behoeften van het volk een belangrijker plaats dan ooit. Het ging er enerzijds om, 'dat de staat, wil hij leiden, zich eerst moet laten doordringen door het leven der maatschappij', zoals

114 Zij hadden immers beginsel-politiek bepleit tegen de liberale ongemandateerde 'Vertrauensmänner' (bijvoorbeeld Kuyper, Slarreniriisen, 16) die vertrouwd werden omdat zij vertrouwen waard waren.

115 Van der Goes, Verkeerde partijleiding, 9; het volgende citaat aldaar. Kuyper, Slarrentritsen, 89: 'De keuze staat tusschen vertrouwen of ontslag'.

116 W. van de Vall, 'Leiders en leiding. Een woord uit Noordholland Noord', in: E. Boekman, e. a., ed., Ir. J. W. Albarda. Een kwart eeuw parlementaire werkzaamheid in dienst van de bevrijding der Nederlandse arbeidersklasse. Een beeld van de groei der Nederlandsche volksgemeenschap (Amsterdam, 1938) 54-55.

117 W. H. Vliegen, 'De parlementariër', in: Boekman, ed., Albarda, 12. 
Quack het in 1885 programmatisch uitdrukte ${ }^{118}$. En omgekeerd greep de staat steeds verder in het maatschappelijk leven in met een beroep op de sociale noden die om een oplossing vroegen ${ }^{119}$.

Deze nieuwe legitimatie van staatsactiviteit ging gepaard met een verandering in het karaktervan de openbaarheid. Zij was niet uitsluitend meer de plaats waar onafhankelijke burgers van mening verschilden over het algemeen belang, maar werd ook het forum waarop onderscheiden groepen hun behoeften en noden naar voren brachten. Vanaf de jaren tachtig gingen die noden steeds meer hun stempel op het politieke debat drukken. Over het bestaan ervan viel steeds minder te twisten, terwijl het meningsverschil steeds meer ging over de vraag wat het zou betekenen als de overheid de noden van specifieke groepen zou lenigen. De retoriek waarmee het volk achter de kiezer werd gemobiliseerd, gaf derhalve niet direct meer burgers een stem, maar vertolkte wel hun behoeften en presenteerde de leniging ervan als legitiem motief voor staatsingrijpen.

Op zich zou deze verandering nog in overeenstemming zijn met de liberale gedachte dat het staatsoptreden verandert, omdat in het openbare debat andere wensen geformuleerd worden. Maar in tegenspraak met de grondslag van de liberale openbaarheid was dat steeds vaker een beroep op de overheid werd gedaan om de noden en behoeften van de bevolking in kaart te brengen. Opmerkelijk daarbij is, dat juist liberalen deze uitbreiding van de overheidstaak hebben gestimuleerd ${ }^{120}$. Zij wilden de kwaliteit van de publieke opinie verbeteren en pleitten daarom voor een uitbreiding van de overheidsstatistiek, zodat burgers een gefundeerd oordeel konden vormen. Behoudende liberalen merkten echter wel het onbedoelde gevolg op van de uitbreiding van de instellingen en de taken van de staat. Dit leidde tot spanningen in het liberale kamp, die erde oorzaak van waren dat sinds 1848 opgeworpen voorstellen voor de oprichting van een centraal bureau voor de statistiek, pas in 1899 verwezenlijkt zouden worden. De discussie over dat bureau is exemplarisch voor de toenemende vervlechting van de openbaarheid met de staat. Net als in het geval van de partijvorming, heeft ook deze ontwikkeling haar wortels in de liberale openbaarheid. De thema's, de infrastructuur en de deelnemers in de openbaarheid veranderden van karakter door de pogingen om de kwaliteit van de liberale openbaarheid te verbeteren.

\section{Statistische kennis als grondslag van de liberale openbaarheid}

Het liberale model van de openbaarheid werd pas na 1848 de grondslag van het

118 H. P. G. Quack, 'Sociale politiek. Rede bij de aanvaarding van het hoogleraarsambt te Amsterdam 29 september 1885', De Gids (1885) iv, 154.

119 J. Romein, Op het breukvlak van twee eeuwen (2e druk; Amsterdam, 1976) hoofdstuk XVIII en XIX.

120 Het opmerkelijke daarvan blijft buiten beeld in N. Randeraad, 'Negentiende-eeuwse bevolkingsregisters als statistische bron en middel tot sociale beheersing'. Tijdschrift voor sociale geschiedenis, XXI (1995) 319-342, doordat hij de ontwikkeling van de statistiek in de lijn van Michel Foucault en Stanley Cohen vooral ziet als instrument van sociale beheersing in handen van een 'liberale staat' en voorbij gaat aan de betekenis van de statistiek na 1848 , als grondslag van de publieke sfeer tegenover de staat. 
politieke bestel: 'De tijd van geheimhouding in de zaken van het staatsbestuur is voorbij', stelde Simon Vissering in 1849,

de veranderde inrigting onzer staatsinstellingen dwingt de regering meer en meer tot openbaarheid; de natie tot kennisneming. Statistiek is de grondslag dier openbaarheid, en met iederen dag zal zich de behoefte aan statistieken kennis krachtiger doen gevoelen ${ }^{121}$.

Vissering onderschreef het credo 'de publieke zaak wil publiek behandeld worden', maar tekende daar onmiddellijk bij aan

dat de belangstelling met kennis gepaard ga, kennis van beginselen en kennis van zaken, zonder welke ... volksoordeel en volksvooroordeel een onweerstaanbaren, schoon dan ook zijdelingschen, invloed op den gang des bestuurs oefenen. En die kennis ontbreekt bijna geheel, althans hare tweede helft ontbreekt, waar geene statistiek gekend wordt ${ }^{122}$.

Daarom moest zo snel mogelijk een einde komen aan de wanordelijke toestand waarin de overheidsstatistiek zich bevond. Weliswaar werd op de verschillende bureaus van de ministeries en in den lande veel materiaal verzameld, maar dit gebeurde zonder orde en eenheid: 'dit is geene statistiek, evenmin als een hoop hout, steen en kalk een huis is $^{\prime 123}$.

De oplossing zag Vissering in de oprichting van een zelfstandig bureau, dat onafhankelijk zou zijn van de regering en de departementen en 'buiten de bewegingen der politiek' zou blijven door 'de wakkere lust tot wetenschappelijke beoefening der wetenschap $^{124}$. Zijn voorstel was met name bedoeld om de systematiek en methodiek

121 S. Vissering, 'De statistiek in Nederland', De Gids (1849) ii, 17. Zie ook J. de Bosch Kemper: 'De publieke opinie is ... de groote beweegkracht, waardoor de Staatkunde wordt bepaald. Wanneer die publieke opinie gevoed wordt door grondige overweging der maatschappelijke behoeften ... kan men daarvan de meeste vruchten voor het Vaderland verwachten". 'Voorwoord', Staatkundig en staathuishoudkundig jaarboekje, 1(1849)15.

122 Vissering, 'Statistiek in Nederland', 6-7.

123 Ibidem, 8. De Nederlandse staat hield voor 1848 al wel gegevens bij over de toestand van het land en de bevolking, armoede en rijkdom, misdaad en straf, handel en nijverheid, openbare werken en waterstaat, het verkeer en de financiën. Een belangrijke aanzet hiertoe was de volkstelling van 1796 ten behoeve van het ontwerpen van kiesdistricten. Met de Staatsregeling van 1798 werden vervolgens speciale agenten in het leven geroepen, belast met het vergaren van informatie over de bevolking. De invoering van Franse administratieve vernieuwingen in de Napoleontische tijd droeg hieraan nog verder bij. Deze lijn werd voorgezet in 1826, toen het ministerie van binnenlandse zaken een Bureau voor de statistiek oprichtte en een commissie belastte met de controle van dit bureau. De dagelijkse leiding van het bureau was in handen van R. Lobatto, die van 1826 tot 1849 een statistisch jaarboekje publiceerde. Ook deed hij het voorstel regelmatig een algemene volkstelling te houden. Hij organiseerde in 1829 de eerste telling, die het model zou worden voor de tellingen die elke tien jaar nadien gehouden werden. Het essentiële verschil met de discussie over statistiek na 1848 is dat deze dan niet langer als arcana imperii wordt beschouwd, maar als bron van voorlichting van de publieke opinie. Zie [H. W. Methorst], 'Geschiedenis van de statistiek in het Koninkrijk der Nederlanden', Bijdragen tot de statistiek van Nederland, nieuwe volgreeks XIV (Den Haag, 1902) 61 e. v.; I. Stamhuis, 'Cijfers en Aequaties' en 'Kennis der Staatskrachten'. Statistiek in Nederland in de negentiende eeuw (Amsterdam-Atlanta, 1989) passim; Ch. Jeurgens, P. M. M. Klep, Informatieprocessen van de Bataafs-Franse overheid 1795-1813 (Den Haag, 1995) 9-13; Randeraad, 'Negentiende-eeuwse bevolkingsregisters', passim. 
van het statistisch onderzoek te bevorderen. Hij sloot daarmee aan bij de mening onder staathuishoudkundigen die zich hadden verenigd voor de uitgave van het Staatkundig en staathuishoudkundig jaarboekje, waar in 1857 de Vereeniging voor de statistiek uit voortkwam.

Op het eerste gezicht werden de voorstanders van de statistiek op hun wenken bediend. Het ministerie van binnenlandse zaken had in 1848 al een nieuw bureau voor de statistiek opgericht. Het hoofd daarvan, M. M. von Baumhauer, schreef een jaar na de oprichting in De Gids, dat de ongeordende staat van 's lands statistiek niet alleen schade toebracht aan de staat en de samenleving, maar ook aan de statistiek, want 'het uitgeven van statistieke tafelen als gelegenheidsstukken verwekt wantrouwen in hare opregtheid bij de natie ${ }^{125}$. De waarde van de statistiek lag in de zekerheid die zij bood. Met name door de ' cijfertaal' waarvan de statistiek gebruik maakte, verschafte ' zij zich de juistheid en zekerheid, welke lijnen en letters den beoefenaars der meet- en stelkunde voor hunne berekeningen opleveren'. Daarnaast lag de waarde van de statistiek in haar precisie en ging zij 'niet theoretisch, maar praktisch en historisch te werk'. De 'statistiek bezoekt tevens de huisselijken haard, en baant zich een weg tot de wetenschap van het innerlijke huisselijke leven'. De 'kennis van de dagelijkschen behoeften' en de aandacht voor het ordelijke dagelijks leven gaf de statistiek volgens Baumhauer bovendien 'eene zekere mate van toekomstvoorspellende waarde'. Goede statistiek was onmisbaar voor de staatsman. Zonder haar zouden hervormingen tot een loterij worden $^{126}$.

Net als andere pleitbezorgers van de statistiek sloot Baumhauer aan bij het werk van Quetelet. Deze Brusselse hoogleraar in de wis- en natuurkunde had vanaf de jaren twintig betoogd dat de normaalverdeling van meetfouten bij natuurkundige experimenter^ ook van toepassing was op de verdeling van fysieke, sociale en morele kenmerken onder de bevolking. Quetelet trok bovendien de vergaande conclusie, dat aan statistische regelmaat ook een causale wetmatigheid ten grondslag lag: de statistiek bood inzicht in de wetten van het maatschappelijk leven en kon de grondslag vormen voor een 'sociale fysica' ${ }^{127}$.

De voorstanders van de statistiek zagen wel dat er met dit determinisme een probleem ontstond. Twee zielen streden in hun liberale borst 'een strijd tusschen de gelijkmatigheid der verschijnselen op maatschappelijk gebied, en den vrijen wil van het individu ', zoals het in de titel luidde van een opstel in De Economist. De auteur schetste daarin een land met wetten die het aantal huwelijken, zelfmoorden en onechte kinderen decreteerden:

Geen magt ter wereld, vereenigde zij oostersch despotisme met Napoleontisme of Bismarcktisme, zoude zoodanige wet kunnen ten uitvoer leggen. En toch geschiedt het, en wel geheel

125 M. M. von Baumhauer, 'De statistiek', De Gids (1849) i, 87.

126 Ibidem, 80.

127 Stamhuis, Cijfers en Aequaties, 56-62; A. Desrosières, La politique des grands nombres. Histoire de la raison statistique (Parijs, 1993) 94-99; I. Hacking, The taming of chance (Cambridge, 1990) 105 e. v.; E. S. Houwaart, 'Medische statistiek', in: H. W. Lintsen, e. a., ed., Geschiedenis van de techniek in Nederland. De wording van de moderne samenleving 1800-1890, II (Zutphen, 1993) 30-35. 
vrijwillig ... En het merkwaardige daarbij is, dat wij op die wijze fungeren als leden van een groot mechanisme en toch eene geheel vrije beweging bezitten, welke evenwel dit mechanisme geheel niet in zijn gang stoort ${ }^{128}$.

De verlossing in deze strijd was het 'karakter'. Ondanks het bestaan van een determinerend mechanisme, kon er toch van 'zedelijke vrijheid' gesproken worden, omdat ons karakter ons in staat stelde het mechanisme te wijzigen ${ }^{129}$. De statistiek maakte derhalve duidelijk hoe moeilijk de maatschappij te veranderen was, maar bood tegelijkertijd een leidraad voor verandering, doordat zij inzicht bood in de werking van het maatschappelijk mechanisme. De statistiek als grondslag van de publieke opinie bood derhalve de belofte van rationeel staatsbeheer. De geheimhouding van voor 1848 was doorbroken, niet om de wil van het volk tot leidraad van het staatsbeheer te maken, maar om de burgers in staat te stellen het staatsoptreden te beoordelen in het licht van het algemeen belang. Getalsmatige kennis van de samenleving was de vaste bodem waarop dat oordeel moest rusten.

\section{Het liberale pleidooi tegen de statistiek}

Alle zegeningen van de statistiek konden echter ook in hun nadeel verkeren. De tegenstanders zagen het kwantitatieve karakter van de statistiek als getalsfetisjisme. Het determinisme leidde tot fatalisme en moreel nihilisme. Het gewroet in huiselijke kring was een ontoelaatbare staatsbemoeienis, die despotische vormen kon aannemen. En zoals de hoofdredacteur van De Economist, De Bruyn Kops in 1854 schreef, werd de statistiek jammer genoeg veelal gezien als 'een vernuftig middel der bureaucratie, om lastige vragen te doen aan gemeentebesturen en om het werk der bureaux te vermeerderen $^{130}$.

De tegenstanders gaven minder ruchtbaarheid aan hun bezwaren dan de voorstanders aan hun enthousiasme. Maar zij waren niettemin in staat lange tijd de oprichting van een zelfstandig centraal bureau voor de statistiek tegen te houden. Het opvallende daarbij is dat de tegenstanders niet slechts te vinden waren onder conservatieven, die vanwege hun particularistische en familiale politieke stijl weinig heil zagen in de openbaarheid van bestuur. Onderde tegenstanders waren ook doctrinaire liberalen, die op basis van liberale argumenten de overheidsstatistiek afwezen.

Het dieptepunt in deze ontwikkeling was het jaar 1878. Twee jaar daarvoor was G. de Bosch Kemper, zoon van Jeronimo, Baumhauer opgevolgd als directeur van het statistisch bureau bij binnenlandse zaken. Zijn voortvarende poging de statistische arbeid grondig aan te pakken stuitte op verzet van de minister, Kappeyne van de

128 H. A. Wijnne, 'Is er een strijd tussen de gelijkmatigheid der verschijnselen op maatschappelijk gebied, en den vrijen wil van het individu?', De Economist, I (1869) 181.

$129 \quad$ Ibidem, 184.

130 J. L. de Bruyn Kops in De Economist (1854) 346, geciteerd in J. Mooij, Denken over welvaart. Koninklijke Vereniging voor de staathuishoudkunde 1849-1994 (Utrecht, 1994) 36. Hoe grillig de lijnen tussen verschillende partijen liepen, blijkt wel uit het feit dat De Bruyn Kops in dezelfde periode waarin hij zich als voorstander van de statistiek opwerpt, tegelijkertijd bekend staat als aanhanger van 'het oude standpunt van Adam Smith'. Zie Stuurman, Wacht op onze daden, 307. 
Coppello. In april 1878 werden de twee medewerkers van De Bosch Kemper overgeplaatst en kreeg de directeur zelf eervol ontslag. Er ontstond een golf van protest; de Vereeniging voor de statistiek stelde een petitie op waarin gevraagd werd om de oprichting van een centraal bureau, en ook uit het buitenland kwamen protesten, onder andere van Engel, de directeur van het Pruisische centrale bureau voor de statistiek. In het Kamerdebat hierover bleek hoezeer binnen het liberale kamp de meningen verdeeld waren. De Kamerleden De Bruyn Kops en Hendrik Goeman Borgesius riepen de minister tijdens de behandeling van de begroting voor 1879 ter verantwoording. Goeman Borgesius erkende dat de statistiek een droog onderwerp was, en 'geen onderwerp waaromtrent zij, die er geen grondige studie van gemaakt hebben, door het houden van een enkele — zij het dan ook eene prachtige — redevoering overtuigd kunnen worden" ${ }^{31}$. Maar men behoefde volgens Goeman Borgesius geen socialist te zijn, om in te zien dat men pas 'door de drooge wetenschap der cijfers' van de werkelijke maatschappelijke toestanden op de hoogte zou raken:

Men heeft ons liberalen altijd verweten, dat wij theoristen zijn die ons niets bekommeren om feitelijke toestanden; welnu, laten wij allen, laat ook de Minister dat verwijt ontzenuwen, door vast te houden aan dien eenigen grondslag, waardoor wij werkel ijk tot kennis van die toestanden kunnen geraken $^{132}$.

Tegen de interpellatie van Goeman Borgesius bracht minister Kappeyne van de Coppello in dat de oprichting van een centraal bureau tot Staatsdespotie zou leiden. Een centraal bureau zou volgens hem pas zin hebben als het ingezetenen eventueel met strafrechtelijke dwang tot waarheidsgetrouwe opgave van de benodigde gegevens kon brengen. Maar meer nog dan tegen het despotische karakter, keerde de minister zich tegen het 'afgoderij plegen met de wetenschap ${ }^{133}$. De statistische wetenschap had volgens hem beperkingen die niet slechts lagen in de onvolkomenheid van het statistisch onderzoek ${ }^{134}$. De wetenschap zou nooit in staat zijn de gegevens te produceren die zij beloofde:

131 Handelingen Tweede Kamer 1878-1879, 9 december 1878, 334. Zie ook H. Goeman Borgesius, 'Nota', Ibidem, Bijlagen Staatsbegroting hoofdstuk V. 11,14-17. Het debat met Kappeyne van de Coppello is een ander voorbeeld van de groeiende spanning vanaf het eind van de jaren zeventig tussen de groep rond Kappeyne en de jongere liberalen, naast de kwesties waar G. Taal, Liberalen en radicalen in Nederland. 1872-1901 (Den Haag, 1980) 52 e. v. melding van maakt. Zie over het onderscheid tussen generaties liberalen: Stuurman, Wacht op onze daden, 294. Deze spanning kan er ook toe hebben geleid dat de ontwikkeling van bevolkingsregisters in de eerste decennia na 1848 op veel weerstand stuitte en dat pas na 1890 aanzetten voor een wettelijke regeling getroffen werden voor registratie op 'gezinspersoonskaarten', die uiteindelijk met een Koninklijk Besluit van 31 maart 1936 (Staatsblad, nr. 342) verplicht werd gesteld. Zie Randeraad, 'Negentiende-eeuwse bevolkingsregisters', 337-339.

132 Handelingen Tweede Kamer 1878-1879, 10 december 1878, 339, 345.

133 Ibidem, 339.

134 In het debat viel de minister direct zijn ontslagen ambtenaar, G. de Bosch Kemper, aan. Ooit had hij hem enkele gegevens gevraagd: 'Ofschoon die vragen zeer eenvoudig waren, moest ik tot mijne verwondering daarop ten antwoord krijgen, dat voor eene rigtige beantwoording het noodig zou zijn eerst gedurende 25 jaren een betere bewerking der statistiek te volgen'. G. de Bosch Kemper had in De Gids zijn visie op de zaak gegeven en gesteld dat '[d]e eigenaardigheid der statistieke bemoeiing hierin is gelegen 
Er zal in de menschelijke handelingen — en daaruit toch bestaat de maatschappij — altijd iets overblijven, wat zich niet onder cijfers laat brengen. In een woord: ook in de menschelijke maatschappij is een menschelijke ziel, die niet toelaat alles op een zuiver materieelen grondslag te construeren.

Om zijn argumenten kracht bij te zetten verwees de minister naar 'den besten kenner van de geschiedenis in ons land-professor Fruin', volgens wie 'de pogingen b. v. van Buckle om de geschiedenis op de statistiek te bouwen' beschouwd konden worden 'als ten eenen male mislukt ${ }^{135}$.

Daarmee trof Kappeyne van de Coppello een teer punt, dat de statistici een tijd had beziggehouden. Het werk van Henry Buckle, History of civilization in England, dat tussen 1857 en 1861 in vijf delen verscheen, was op het internationale statistische congres van 1860 afgeschilderd als voorbeeld van het excessieve determinisme waarin Quetelets denken kon ontaarden. Naar aanleiding van deze debatten raakte overal in Europa de gedachte in zwang dat statistiek niet deterministisch en voorspellend was, maar beschrijvend en historisch ${ }^{136}$. Dat gebeurde ook in Nederland ${ }^{137}$.

\section{Nieuwe thema's in de openbaarheid}

De voorstanders van de nieuwe statistiek, tegelijk de aanhangers van de historische school, zouden vanaf de jaren tachtig een vooraanstaande positie binnen de overheid gaan innemen. Zij gaven de statistiek een vaste plaats in de openbaarheid, zowel door een groter beroep te doen op statistische gegevens in het openbare debat, als door de statistiek tot erkend onderdeel van het staatsapparaat te maken. Daarmee creëerden zij nieuwe thema's in de publieke sfeer.

De oprichting van een centraal bureau voor de statistiek was slechts een van de latere Produkten van deze omslag. In 1892 stelde N. G. Pierson als minister van financiën samen met Tak van Poortvliet op binnenlandse zaken een Centrale commissie voor de statistiek in. Een van de leden was, naast Goeman Borgesius en Quack (toen voorzitter van de Vereeniging voor de statistiek), C. A. Venijn Stuart, die in 1899 de eerste directeur van het Centraal bureau voor de statistiek zou worden. De daadwerkelijke oprichting daarvan ging uiteindelijk vrijwel geruisloos. Venijn Stuart had na zes jaar al 45 personeelsleden in dienst, een aantal dat in de vijftien jaar daarna meer dan verviervoudigde ${ }^{138}$.

dat dikwijls eerst uit het resultaat der werkzaamheden kan blijken, of zij voorde regeering dan wel voor de burgers noodig is geweest, G. de Bosch Kemper, 'De officieele statistiek', De Gids (1878) iv, 15.

135 Handelingen Tweede Kamer 1878-1879, 9 december 1878, passim.

136 I. Hacking, 'Prussian Numbers 1860-1882', in: L. Krüger, L. J. Daston, M. Heidelberger, ed., The Probabilistic Revolution (Cambridge (Ma.)-Londen, 1987) 377-394.

137 Die opvatting van de statistiek sloot beter aan bij de 'historische school' dan de statistiek op individualistische grondslag, die eerder geassocieerd werd met de klassieke politieke economie. Zie T. J. Boschloo, De produktiemaatschappij. Liberalisme, economische wetenschap en het vraagstuk der armoede in Nederland (Hilversum, 1990) $236 \mathrm{e}$. v. Deze overgang wordt door R. Aerts geïnterpreteerd als een breuk, die zich na 1870 in de hele liberale denkwereld voltrok. Zie R. Aerts, e. a., De Gids sinds 1837. De geschiedenis van een algemeen cultureel tijdschrift (Den Haag-Amsterdam, 1987) 64. Zie ook E. S. Houwaart, De hygiennisten. Artsen, staat en volksgezondheid in Nederland (Groningen, 1991).

138 Zie Methorst, Geschiedenis, 38 e. v.; Stamhuis, Cijfers en Aequaties, 222 e. v.; Mooij, Denken over welvaart, 60 e. v. 
Deze ontwikkeling demonstreerde dat Kappeynes argumenten tegen de statistiek hun overtuigingskracht hadden verloren. Niettegenstaande zijn bewering dat de statistiek praktisch nut ontbeerde, gingen politici in de Kamer, schrijvers in de pers en functionarissen in het overheidsapparaat steeds meer van statistieken gebruik maken. Dat zoiets gaande was, constateerde Goeman Borgesius al in het Kamerdebat van 1878:

Is er bij de langdurige beraadslagingen één spreker geweest, die zich niet heeft beroepen op cijfers en niet betreurd heeft, dat er met betrekking tot het onderwerp, door hem behandeld, geene betere statistiek bestond ${ }^{139}$ ?

Medici hechtten al in de jaren zestig en zeventig een grote waarde aan statistiek. In de discussie over de wet besmettelijke ziekten, die ontstond naar aanleiding van epidemieën van cholera, tyfus en pokken rond 1870, was een patstelling ontstaan over de vraag naar de precieze oorzaken van besmettelijke ziekten. Zonder een uitspraak te doen over een oorzakelijk verband, toonde de statistiek nu in ieder geval een samenhang tussen de openbare hygiëne en het optreden van ziekten ${ }^{140}$.

Een nog grotere betekenis zou de statistiek krijgen op het gebied van de arbeidswetgeving. Goeman Borgesius sprak de minister aan als 'vader der wet op den kinderarbeid', die dooreen gebrek aan gegevens genoodzaakt was zich 'tevreden te stellen met eene wet, waarin nog weinig meer dan een beginsel werd neergelegd'. Zelfs Goeman Borgesius schroomde, als voorstander van grotere staatsinterventie, om nieuwe wetgeving voor te stellen, zolang de effecten van de huidige niet bekend waren. In de jaren tachtig en negentig werden daarom steeds meer gegevens verzameld, getuige de Arbeidsenquête van 1887. Bovendien werd vooruitgang geboekt in de bewerking van diFgêgevêns". Daarbij kon voortgebouwd worden op de verzekëringsstatïstiek dié äl veel langer bestond in de vorm van sterftetafels en die al voor 1848 met name door de bijdragen van Lobatto een zekere mathematische perfectionering hadden gekregen. Bovendien veranderde in het laatste kwart van de negentiende eeuw de optiek op arbeidsongevallen. In plaats van persoonlijke aansprakelijkheid werden professionele risico's de grondslag voor de verzekering van ongevallen en tegenslagen. Risico's, en daarmee de benodigde premies en mogelijke uitkeringen, waren een kwestie van statistische regelmaat $^{141}$.

Het gebruik van statistische gegevens veranderde de vorm van openbare debatten en daarmee van de legitimering van politieke machtsuitoefening. Ten eerste bracht de statistiek een tweedeling tot stand in de publieke sfeer. Terwijl voordien alle burgers in beginsel konden meepraten, legden de voorstanders en de tegenstanders de nadruk op het punt dat statistiek wetenschappelijk was en daarom moeilijk. Voor de tegenstanders was dit een argument tegen het praktische nut van de statistiek. Voor de voorstanders was het daarentegen de belangrijkste reden om te pleiten voor een zelfstandig

139 Handelingen Tweede Kamer 1878-1879, 9 december 1878, 336.

140 Houwaart, 'Medische statistiek', 40.

141 Zie F. Ewald, L'Etat Providence (Parijs, 1986) 177 e. v.; R. Schwitters, De risico's van de arbeid. Het ontstaan van de Ongevallenwet 1901 in sociologisch perspectief (Groningen, 1991) 290. 
bureau. Om op een zinnige manier van statistiek gebruik te maken was een wetenschappelijke vorming nodig. Met de oprichting van het Centraal bureau trokken de voorstanders aan het langste eind. Zij creëerden daarmee een instantie die, zoals zij zelf ook altijd bedoeld hadden, buiten het politieke debat stond, maar die wel steeds kon worden aangeroepen om het eigen gelijk te bevestigen. Naast de deelnemers aan het politieke debat ontstond daarmee een nieuwe groep van 'denkers, buiten eenige practische politiek staande', zoals Quack hen in zijn inaugurale rede noemde:

Terwijl de staatslieden zich te goed deden aan de holle phrases der politiek, en alléén oor hadden voor het rumoer en het geraas dat de luidklinkende feiten van den dag veroorzaakten, poogden zij te luisteren naar den zonder veel gedruisch voortrollenden stroom der menschelijke samenleving $^{142}$.

Op nog een tweede manier veranderde het openbare debat door het gebruik van statistische gegevens. Nadat het radicale determinisme van Quetelets statistiek was verdwenen, bestond de statistiek die in het laatste kwart van de eeuw in zwang raakte, vooral uit geaggregeerde aantallen. Daaruit werden geen wetmatigheden met een voorspellende waarde afgeleid, maar slechts tendensen en samenhangen. Dit paste in het beeld van de maatschappij als organische eenheid, die groeide of verviel. Die ontwikkeling was niet direct stuurbaar, maar vergde prudente meegaandheid. Daardoor was in de maatschappij zelf al een vorm van samenwerking, met name tussen ogenschijnlijk antagonistische klassen, geïncorporeerd ${ }^{143}$.

De statistiek gaf dat organische ideaalbeeld een ontologische onderbouwing. Met de geaggregeerde cijfers konden politieke en sociale scheidslijnen overschreden en vervangen worden door andere, minder omstreden onderscheiden. Zo bracht de medische statistiek de gezondheidstoestand van de bevolking in beeld. De eenheid was niet individu of klasse, maar eerder buurt, gemeente of regio. De statistiek schiep daardoor nieuwe eenheden, waarin eventueel door de staat kon worden ingegrepen. Tegelijk ontstonden zo nieuwe thema's voor de publieke opinie. Als onderdeel van statistische categorieën als morbiditeit, mortaliteit of woonsituatie waren burgers gelijkelijk onderworpen aan maatschappelijke veranderingen. Verschillen in individuele voorspoed golden niet langer als persoonlijke verdienste, maar konden herleid worden tot onderliggende maatschappelijke voorwaarden ${ }^{144}$.

\section{Een nieuwe infrastructuur van de openbaarheid}

Het samenvoegen van gegevens over individuen tot numerieke eenheden op een hoger, gemeenschappelijk niveau was niet alleen een intellectuele vernieuwing, maar ook een administratieve operatie. De oprichting van het Centraal bureau voor de statistiek was

142 Quack, 'Sociale politiek', 155, 157.

143 Zie P. de Rooy, Darwin en de strijd langs vaste lijnen (Nijmegen, 1987).

144 Houwaart, 'Medische statistiek', 40; E. S. Houwaart, 'Professionalisering en staatsvorming', in: H. W. Lintsen, e. a., ed., Geschiedenis van de techniek in Nederland. De wording van een moderne samenleving, 1800-1890, II (Zutphen, 1993) 84. 
een belangrijke episode in de ontwikkeling van de Nederlandse staat. Vanaf de oprichting van het Centraal bureau was het verzamelen van gegevens niet langer iets waarover gemeenten, provincies en andere departementen dan dat van binnenlandse zaken naar eigen inzicht konden beslissen. Het bureau verzamelde de gegevens op een centraal punt, waartoe bestuurders van alle geledingen zich in toenemende mate moesten wenden om informatie over hun omgeving te krijgen. De vorming van het Centraal bureau was daarmee exemplarisch voor de explosieve groei van de overheidsadministratie in de jaren vanaf de eeuwwisseling en voor de nieuwe infrastructuur van de openbaarheid ${ }^{145}$.

De toename van het aantal onderdelen van de overheidsdienst en van het aantal ambtenaren ging gepaard met professionalisering. Tot het eind van de eeuw kende de ambtenarenstand veel familiale bindingen en een sterk standsbewustzijn. Het ambtenarenethos kenmerkte zich door 'trouwe plichtsvervulling, geduldig wachten op bevordering op grond van het anciënniteitsstelsel, de gulden middelmaat en zelfgenoegzaamheid ${ }^{146}$. Aan het eind van de eeuw veranderde dit langzamerhand. Ambtenaren gingen langer werken dan de enkele uren die ze tot dan toe per dag actief waren en gingen voor hun groeiende contacten met de buitenwereld steeds meer gebruik maken van vaste routines en formuliere ${ }^{147}$. Het gevolg was dat de categorieën waarvan ambtenaren gebruik maakten ook buiten de bureaus van de ministeries een rol gingen spelen. Ook het ambtelijk taalgebruik, waarover P. H. Ritter in een vroege studie naar de Nederlandse bureaucratie met een understatement opmerkte, dat 'de ambtelijke briefschrijver in den regel verzuimt de aandacht van zijn lezer te prikkelen $^{148}$, ging zo na 1900 in toenemende mate de openbaarheid kleuren.

De totstandkoming van het Centraal bureau voor de statistiek laat bovendien zien dat de vervlechting van staat en openbaarheid niet zonder meer als 'verstatelijking' van de openbare sfeer kan worden betiteld. Opvallend is juist dat een belangrijk deel van de groeiende rol van de staat te herleiden is tot activiteiten buiten de staat. Zo kwamen de belangrijkste initiatieven voor een overheidsstatistiek voort uit de groep van staathuishoudkundigen, die zich georganiseerd hadden in de Vereeniging voor statistiek. Hun activiteiten waren voorafgegaan door vooralsnog vruchteloze lokale initiatie$\operatorname{ven}^{149}$.

Vernieuwingen van de staat hadden daarenboven niet alleen hun oorsprong vaak in openbare initiatieven; uit de geschiedenis van de statistiek blijkt ook dat toenemende activiteit op centraal niveau veelal gepaard ging met groeiende activiteiten op lokaal niveau. In dezelfde periode dat de Centrale commissie voor de statistiek na 1892 tot broedplaats van het Centraal bureau voor de statistiek werd, richtte Ph. Falkenberg in Amsterdam het Gemeentelijk bureau voor de statistiek op. Dit zou vervolgens een belangrijke rol moeten vervullen bij het opzetten van een werkloosheidsverzekering

145 Van IJssclmuiden, Binnenlandse Zaken, 132-133, 145.

146 - N. Randeraad, 'Ambtenaren in Nederland (1815-1915)', BMGN, CIX (1994) 221.

147 Van IJsselmuiden, Binnenlandse Zaken, 150 e. v., 192.

148 Randeraad, 'Ambtenaren', 218; P. H. Ritter jr., 'De ambtelijke taal', in: J. H. de Goede jr., ed., Hel orkest der overheid. Ambtenaren op hunpost (Alphen aan den Rijn, 1939) 105.

149 Stamhuis, Cijfers en Aequaties, 184-187. 
en arbeidsbemiddeling. Terwijl de organisatie daarvan in eerste instantie ter hand werd genomen door werknemers en werkgevers, mondde dit uiteindelijk uit in een gemeentelijk Fonds ter bevordering van de verzekering tegen de geldelijke gevolgen van werkloosheid en in het opzetten van de Centrale arbeidsbeurs, die in 1909 samen met beurzen van andere gemeenten samenging in de Vereniging van Nederlandsche arbeidsbeurzen. De subsidie die deze vereniging vanaf 1910 ontving, is volgens De Rooy te beschouwen als de eerste overheidssteun in de werkloosheidsbestrijding ${ }^{150}$. De meeste vormen van gegevensverzameling, inspectie en zorg dankten hun ontstaan aan initiatieven buiten de staat, maar al gauw kreeg de staat een rol in het verder ontwikkelen van de infrastructuur die daarvoor nodig was. De staat schiep vervolgens het kader waaraan nieuwe initiatieven in de maatschappij juridisch, financieel of organisatorisch gebonden werden. Dit moet niet als toenemende greep van de staat op de openbaarheid worden begrepen, maar eerder als symptoom van een onderling afhankelijke transformatie van staat en openbaarheid.

\section{Nieuw politiek personeel}

Deze wisselwerking maakte het ook mogelijk dat nieuwe verenigingen, lokale instellingen en centrale ambtelijke diensten de kweekvijver werden voor een nieuwe politieke klasse. De leden van de politieke elite troffen elkaar steeds minder in bolwerken van behoudend liberalisme en nieuwkomers werden langzamerhand uit iets andere hoek dan de juridische faculteiten gerecruteerd ${ }^{151}$. Zo was een toenemend aantal deelnemers aan het openbare debat opgeleid als ingenieur. Zij vonden met name emplooi bij het departement van waterstaat, handel en nijverheid. In de jaren negentig gaven zij aan het departement leiding in de persoon van J. P. Havelaar (1888-1891), C. Lely (1891-1894 en 1897-1901) en P. W. van der Sleyden (1894-1897). Veel van deze ingenieurs waren in Delft opgeleid door B.H. Pekelharing en ontleenden aan zijn onderwijs de roeping hun talenten voor de gemeenschap in te zetten. Zij beschouwden het ingenieursschap niet alleen als een technische vaardigheid, maar pretendeerden ook als 'sociale ingenieurs' een publieke rol te kunnen spelen. Hier zat ook enige naijver achter, die zich met name tegen juristen richtte. Zo beklaagde de hoofdredacteur van De Ingenieur R. van Sandick zich in 1903,

dat juristen en nog eens juristen de leidende plaats innemen bij alles wat er in Nederland geschiedt, aan welke juristen wij dan van tijd tot tijd een door hen gevraagd advies mogen geven $^{152}$.

De exacte wetenschap stond in hoog aanzien en ingenieurs achtten zich daarom zeer geschikt voor publieke ambten. Zo werd Lely in de lofrede die bij zijn afscheid na 1901

150 ZieP.de Rooy, Werklozenzorg en werkloosheidsbestrijding 1917-1940. Landelijk en Amsterdams beleid (Amsterdam, 1979) hoofdstuk 1.

151 Zie J. van den Berg, De toegang tot hel Binnenhof De maatschappelijke herkomst van TweedeKamerleden tussen 1849 en 1970 (Weesp, 1983); Stuurman, Wacht op onze daden, 293.

152 Geciteerd in $\mathrm{H}$. Lintsen, Ingenieurs in Nederland in de negentiende eeuw. Een streven naar erkenning en macht (Den Haag, 1980) 297. 
werd afgestoken, vooral ook geëerd, omdat hij had bewezen 'dat de ingenieur, die streng wetenschappelijk is opgeleid ... bij uitstek geschikt is voor hoogere leiding' 153. De opmerkelijke presentie van de ingenieurs werd vooral belichaamd door J. W. Albarda. Ook hij was leerling van Pekelharing en was, voordat hij Troelstra opvolgde als partijleider, directeur van de Centrale arbeidsbeurs in Amsterdam en voorzitter van de Vereniging van Nederlandsche arbeidsbeurzen. Bij zijn vijfentwintigjarig lidmaatschap van de Kamer stelde W. H. Vliegen:

Het is een goed ding, dat in deze tijd de leider der sociaal-demokratische fractie een ingenieur is, wiens opleiding meer dan die van een jurist of een ander vak, gericht is op zakelijkheid ${ }^{154}$.

Zakelijkheid was een element dat in meer beschouwingen over de veranderende stijl van politici rond 1900 wordt opgemerkt. Zo typeerde Netscher Goeman Borgesius als iemand met een 'zaakkundig, belangeloos en helder hoofd', die zijn redevoeringen placht te beginnen met de vaststelling dat er al 'veel te lang naar zijn zin gepraat en de zaak onnoodig verward' was ${ }^{155}$. Van der Mandere tekende daar bij aan dat ook Goeman Borgesius

daar, waar naast het logisch gevoel het meer uitsluitend menschelijk sentiment naar voren mag treden, ineens [wist] door te dringen tot de kern van het geheel en die kem voor allen open te leggen $^{156}$.

De moeizame tegenstelling tussen 'logisch gevoel' en 'menschelijk sentiment' geeft al aan dat rond 1900 de nieuwe rol van de politicus nog niet uitgekristalliseerd was. Er bleef een spanning bestaan tussen de politicus die zijn achterban moest enthousiasmeren met een beroep op beginselen, en de politicus als organisator van de staat van wie vooral zakelijkheid en praktische zin verlangd werd. Zo merkte de voorzichtige sociaal-democraat Polak naar aanleiding van Troelstra's revolutiepoging van 1918 op, dat Troelstra als 'onbedachtzaam lyricus' veel met Kuyper gemeen had maar toch onmisbaar was ${ }^{157}$. Beide typen politici verschilden echter radicaal van de politicus van de liberale openbaarheid, die zich kenmerkte door juridische afstandelijkheid en abstractie. De politieke retor smeedde een gevoelsgemeenschap met zijn achterban, de zakelijke politicus wilde vooral pragmatisch optreden in het belang van zijn achterban, maar beiden hielden expliciet rekening met sentimenten en behoeften. Tegelijkertijd kan nu geconstateerd worden dat deze combinatie van een verheven en een pragmatische politieke stijl niet pas met de verzuiling ontstond, zoals Lijphart en velen na hem

153 Redevoering bij diner van de Vereniging van burgerlijk ingenieurs in 1902 ter gelegenheid van het vertrek van C. Lely als gouverneur naar Suriname, geciteerd in Lintsen, Ingenieurs, 342.

154 W. H. Vliegen, 'De parlementariër', in: Boekman, ed., Albarda, 13. Maar Vliegen voegde er aan toe: 'Er zijn ook ingenieurs wien gezwam in de ruimte heel wat beter afgaat dan konstruktieve zakelijkheid. Getuige Mussert'.

155 Netscher, In en om de Tweede Kamer, 108.

156 H. van der Mandere, 'Mr. Hendrik Goeman Borgesius', Mannen en vrouwen van beteekenis in onze dagen, XLII ( 1912) 9.

157 Bloemgarten, Polak, 463. 
beweren. Al ver voor de pacificatie ontkiemden deze twee politieke stijlen in het kweekbed van de liberale openbaarheid.

\section{Naar een nieuwe historiografie van de openbaarheid}

In de tweede helft van de negentiende eeuw veranderden niet alleen de politieke machtsverhoudingen en de inhoud van politiek, maar ook de vorm ervan en de context, de openbaarheid. Liberalen meenden dat de publieke opinie pas goed geïnformeerd en onbevooroordeeld kon zijn als ze vrij was van sentimenten en persoonlijke voorkeuren. Maar de openbaarheid werd tot een strijdperk van partijen, geleid door voormannen die op het gevoel speelden, die niet wilden debatteren om de waarheid boven te laten komen, maar om te getuigen van rotsvaste beginselen, onvatbaar voor weerlegging door de feiten. De openbaarheid zou verder volgens liberalen als een van de staat onafhankelijke instantie de staat moeten leiden. Maar in plaats daarvan raakten de openbaarheid en de staat steeds verder vervlochten, juist als gevolg van de pogingen om de publieke opinie voor te lichten en de zelfstandigheid van de burgers te vergroten. Deze pogingen hadden als paradoxaal gevolg dat de voorwaarde van deskundigheid de toegankelijkheid van de openbare discussie feitelijk inperkte. Deze veranderingen kwamen voor een deel uit de openbaarheid zelf voort en werden voor een ander deel door de staat opgeroepen. Liberalen wensten politieke discussie, maar politiek meningsverschil leidde tot de vorming van politieke partijen die druk uitoefenden om nieuwe vormen van staatsinterventie af te dwingen. Anderzijds ging de staat steeds meer voorlichting, inspectie en deskundigheid aanbieden.

De politieke neergang van de liberalen is vaak genuanceerd met de verwijzing naar de belangrijke positie die zij in de twintigste eeuw wisten te behouden in onder meer overheidsdienst en media ${ }^{158}$. Op basis van het voorafgaande kan worden betoogd dat dit grotendeels een Pyrrhus-overwinning was, want de overheid die zij dienden, was niet meer dezelfde als die van de eeuw daarvoor, evenmin als de openbaarheid van waaruit de overheid gecontroleerd zou moeten worden nog een liberale openbaarheid was. Het cultuurpessimisme dat daarvan onder vrijzinnige notabelen in de twintigste eeuw soms het gevolg was, klinkt door in Habermas' kenschets van een tweede fase in de ontwikkeling van de openbaarheid als Verfallsgeschichte. Uit bovenstaand verhaal blijkt dat deze opvatting discutabel is. Ten eerste is de teloorgang van de liberale openbaarheid niet het gevolg van de gebrekkige realisatie van een rechtvaardig ideaal. Juist middelen om de liberale openbaarheid optimaal te laten functioneren als debating clubs en statistiek waren het begin van de vorming van een nieuwe openbaarheid. Ten tweede gaat de cultuurpessimistische historiografie voorbij aan de waarde van de door partijstrijd en sentiment gekenmerkte openbaarheid. Na het egalitarisme van het vrije debat in de politiek kwam nu het egalitarisme als uitgangspunt voor de leniging van

158 Zie I. Schöffer, 'De Nederlandse confessionele partijen 1918-1939', in: G. A. M. Bekelaar, ed., Vaderlands verleden in veelvoud. 31 Opstellen over de Nederlandse geschiedenis na 1500 (Den Haag, 1975) 602-621 ; S. Stuurman, Verzuiling, kapitalisme en patriarchaat. Aspecten van de ontwikkeling van de moderne staat in Nederland (Nijmegen, 1983) 102; J. J. Woltjer, Recent verleden. De geschiedenis van Nederland in de twintigste eeuw (Amsterdam, 1992) 122. 
achterstelling en nood in de maatschappij. Bovendien is het de vraag of de hiërarchie van leiding en achterban wel een achteruitgang betekende ten opzichte van de uitsluiting van vrouwen en volksklassen in de liberale openbaarheid.

De pessimistische historiografie moet echter ook niet eenvoudigweg omgekeerd worden. Het ontstaan van een door partijdigheid en behoefte verdeelde openbaarheid wordt dan begrepen als emancipatie en bewustwording. Deze zouden tot uitdrukking komen in eigen organisaties (verzuiling) en in het forceren van de toegang tot de staat. Zo'n redenering reduceert de vorm van de politiek tot een afspiegeling van onderliggende maatschappelijke veranderingen en gaat voorbij aan de zelfstandige betekenis van de inrichting en werking van de openbaarheid. Wij hebben getracht te tonen dat de representatie van maatschappelijke tegenstellingen, belangen en behoeften een afzonderlijk moment in de politieke geschiedenis is. We hebben ook betoogd dat emotie een niet weg te redeneren plaats inneemt in politiek - de overgang van de ene naar de andere vorm van politiek ging gepaard met een stijlbreuk, een verandering van vormen en emoties. Wie wil begrijpen wat politiek is en was, zal deze zaken serieus moeten nemen: vorm is meer dan verpakking. Inhoud en vorm zijn wellicht niet te scheiden, maar dat betekent niet dat de een tot de ander herleid kan worden. De historiografie van de openbaarheid, waaraan wij een bijdrage hebben willen leveren, zou vanuit die gedachte verder ontwikkeld moeten worden. 